\title{
Two new species of snail-eating snakes of the genus Tropidodipsas (Serpentes, Dipsadidae) from southern Mexico, with notes on related species
}

\author{
Christoph I. Grünwald 1,2,3, Sarahi Toribio-Jiménez ${ }^{4}$, Carlos Montaño-Ruvalcaba ${ }^{2,3}$, \\ Héctor Franz-Chávez ${ }^{2,3}$, Miguel A. Peñaloza-Montaño ${ }^{5}$, Eduardo Y. Barrera-Nava ${ }^{5}$, \\ Jason M. Jones ${ }^{2,3}$, Christopher M. Rodriguez ${ }^{6}$, India M. Hughes ${ }^{7}$, \\ Jason L. Strickland ${ }^{7}$, Jacobo Reyes-Velasco ${ }^{2,3}$ \\ 1 Biencom Real Estate, Carretera Chapala-Jocotepec \#57-1, C.P. 45920, Ajijic, Jalisco, Mexico. \\ 2 Biodiversa A.C., Avenida de la Ribera \#203, C.P. 45900, Chapala, Jalisco, Mexico. \\ 3 Herp.mx A.C. C.P. 28989, Villa de Álvarez, Colima, Mexico. \\ 4 Centro de Ciencias de Desarrollo Regional, Universidad Autónoma de Guerrero. Calle Pino s/n. Col. El Roble. C.P. 39640. Acapulco, \\ Guerrero, Mexico. \\ 5 Facultad de Ciencias Químico Biológicas, Universidad Autónoma de Guerrero. Avenida Lázaro Cárdenas \#88, Ciudad Universitaria Sur \\ C.P. 39074, Chilpancingo de los Bravo, Guerrero, Mexico. \\ 6 Los Angeles Zoo and Botanical Gardens, 45333 Zoo Drive, Los Angeles, P.C. 90027, California, USA. \\ 7 Department of Biology, University of South Alabama, 5871 USA Dr. N., Mobile, P.C. 36688, Alabama, USA.
}

http://zoobank.org/2977AAFF-677C-46FE-8891-4EC1E1FE6EF3

Corresponding author: Christoph I. Grünwald (cgruenwald@switaki.com)

Academic editor: Günter Gollmann • Received 29 May 2021 • Accepted 18 October 2021 • Published 11 November 2021

\begin{abstract}
We describe two new species of Tropidodipsas related to the T. fasciata species group as defined by Kofron (1987), and provide morphological and molecular data to support the novelty of both species. A partial molecular phylogeny of the Mexican species of snail-eating snakes (Serpentes, Dipsadidae) is presented, and we discuss evolutionary relationships as supported by our molecular results. We analyze specific relationships of the new species described herein with their closest relatives. We present a distribution map for all species of Tropidodipsas and include photographs of living individuals of each species. Finally, we discuss other taxonomic changes based on our molecular phylogeny as well as conservation priorities of the new species.
\end{abstract}

\section{Resumen}

Describimos dos nuevas especies de Tropidodipsas relacionadas al grupo de T. fasciata definido por Kofron (1987), y presentamos evidencia morfológica y molecular que demuestran que estas especies son nuevas. Presentamos una filogenia molecular de las especies Mexicanas de caracoleras (Serpentes: Dipsadidae), y discutimos las relaciones generales según nuestros resultados. Analizamos las relaciones evolutivas de las nuevas especies con las especies más cercanas. Presentamos además mapas de distribución de todas las especies del género Tropidodipsas e incluimos fotografías en vida para cada especies. Finalmente discutimos otros cambios taxonómicos basados en nuestra filogenia molecular, así como prioridades de conservación para las nuevas especies.

\section{Kurzfassung}

Wir beschreiben zwei neue Arten von Tropidodipsas, die mit der von Kofron (1987) definierten T. fasciata-Artengruppe verwandt sind, und liefern morphologische und molekulare Daten, um die Neuheit beider Arten zu unterstützen. Eine partielle molekulare Phylogenie der mexikanischen Arten schneckenfressender Schlangen (Serpentes, Dipsadidae) wird vorgestellt, und wir diskutieren evolutionäre Beziehungen, die durch unsere molekularen Ergebnisse gestützt werden. Wir analysieren spezifische Beziehungen der hier beschriebenen neuen Arten zu ihren nächsten Verwandten und besprechen andere taxonomische Veränderungen, die auf unserer molekularen Phylogenie basiert sind. Wir präsentieren eine Verbreitungskarte für alle Arten von Tropidodipsas, sowie Fotos von lebenden Exemplaren jeder Art. Abschließend geben wir Schutzprioritäten der neuen Arten an. 


\section{Key Words}

conservation, cloud forest, Geophis, Guerrero, Oaxaca, pine-oak woodland, Sierra Madre del Sur

\section{Palabras Claves}

bosque de niebla, bosque de pino-encino, conservación, Geophis, Guerrero, Oaxaca, Sierra Madre del Sur

\section{Schlüsselwörter}

Geophis, Guerrero, Kiefern-Eichen Wald, Naturschutz, Nebelwald, Oaxaca, Sierra Madre del Sur

\section{Introduction}

The herpetofaunal diversity of southern Mexico in the states of Guerrero and Oaxaca is among the richest in the country (Mata-Silva et al. 2015; Palacios-Aguilar and Flores-Villela 2018). However, the rugged sierras in this region are also some of the least explored areas in the country. This is partially due to the difficulty of accessing these mountain ranges because of the lack of good roads, combined with political and social conflicts and illegal narcotics production. Despite these issues, biologists continue to study these areas, and novel taxa are discovered in the region each year. In the past 15 years, 8 species of snakes as well as a new snake genus have been described from this region (Campbell and Flores-Villela 2008; Pavón-Vázquez et al. 2011; Campbell 2015; Campillo et al. 2016; Campbell et al. 2018; Canseco-Márquez et al. 2018; García-Vázquez et al. 2018; Hernández-Jiménez et al. 2019).

The snake family Dipsadidae is one of the most species-rich, and is distributed throughout the Americas, especially the Neotropics, as well as in southeast Asia (Figueroa et al. 2016; Pyron et al. 2011; Uetz 2021; Zheng and Wiens 2016). Among the Dipsadidae, a subset of genera ("goo eaters") have specialized in feeding on invertebrate prey: Dipsas Laurenti 1768, Sibon Fitzinger 1826, Sibynomorphus Fitzinger 1843, Tropidodipsas Günther 1858 and Geophis Wagler 1830. Because of their diet specialization on slugs and snails, species of the genera Dipsas, Tropidodipsas and Sibon are referred to as snail-suckers (the name which we will use from now on).

Multiple authors have used morphological characters to study the taxonomy and systematic relationships among these snakes (Peters 1960; Kofron 1980, 1982, 1985a, 1985b, 1987, 1988, 1990; Wallach 1995; Smith et al. 2005), whereas Sheehy (2013), in an unpublished PhD dissertation, incorporated molecular data to resolve some long-standing questions regarding the systematics of the group. Although recent studies have combined morphological and molecular data to address the systematics of some members of the South American species groups of snail-suckers (Harvey 2008; Harvey and Embert 2008; Arteaga et al. 2018), multiple taxonomic questions remain unanswered, particularly regarding Mexican and Central American taxa. Some of these questions concern the generic placement of several North American species (e.g., Sibon sanniolus, Tropidodipsas sartorii species group, T. fischeri, Dipsas gaigeae, D. brevifacies), the validity of the genera in Mexico and Central America, and the definition of some of the wider ranging species (e.g., Tropidodipsas fasciata, T. sartorii).

While conducting herpetofaunal surveys in several mountain ranges in the states of Guerrero and Oaxaca, we obtained multiple individuals of two distinct species of snakes of the genus Tropidodipsas (Serpentes, Dipsadidae) that we could not allocate to any currently described species. After comparing these specimens to other taxa using both morphological and molecular data, we identified them as undescribed species which we describe herein. To resolve the taxonomy of our recently discovered species of snail-suckers from southern Mexico, we used nuclear and mitochondrial loci to assess the phylogenetic placement of the new taxa among the snail-suckers genera. We additionally discuss some taxonomic issues with the Mexican species of snail-suckers.

\section{Materials and methods}

\section{Taxonomic Sampling}

Between 2004 and 2020 we collected multiple specimens of two undescribed species of snail-suckers in the states of Guerrero and Oaxaca, Mexico. Additionally, we collected other species of snail-suckers from across Mexico to serve as comparative material. Currently, thirteen species of snail-suckers are known from Mexico. These thirteen species are distributed among three genera: four are currently assigned to Sibon, two to Dipsas and seven to Tropidodipsas. Tropidodipsas fasciata and $T$. sartorii have two subspecies each in Mexico and $T$. fischeri has two subspecies, one of which occurs in Mexico. Of these, we sampled three of the four species of $\mathrm{Si}$ bon known from Mexico, both species of Dipsas and five out of the seven species of Tropidodipsas. We were not able to sample Tropidodipsas repleta Smith, Lemos-Espinal, Hartman \& Chiszar, 2005; T. zweifeli Liner \& Wilson, 1970; the subspecies T. fasciata kidderi; T. sartorii macdougalli; Sibon linearis Pérez-Higareda, López-Luna \& Smith 2002; nor the population of T. cf. philippii from Oaxaca reported by Kofron (1987). Additionally, we sampled four species of Geophis which belong to two 
species groups that are hypothesized to be closely related to snail-suckers (Sheehy 2013).

We photographed all live snakes, including dorsal, lateral, and ventral profiles, and euthanized them with pentobarbital. We took tissue samples from muscle or liver upon death and preserved them in $96 \%$ ethanol. We fixed specimens in $10 \%$ formalin and transferred them to $70 \%$ ethanol for permanent storage.

The material collected was deposited at the Instituto de Investigaciones sobre los Recursos Naturales (INIRENA) of the Universidad Michoacana de San Nicolás de Hidalgo (UMSNH) in Morelia, Mexico; the Museo de Zoología, Facultad de Ciencias (MZFC) of the Universidad Nacional Autónoma de México (UNAM) in Mexico City; the Colección Herpetológica de la Facultad de Ciencias Biológicas (CHFCB) of the Universidad Juárez del Estado de Durango (UJED) and the University of Texas at Arlington, Texas (UTA). Although we formally accessioned the specimens we collected, several specimens examined from both the MZFC and UTA collections have not been catalogued, in which case we list the original field numbers and the respective museum in which they were deposited. Original field number abbreviations are as follows: CIG (Christoph I. Grünwald) to be catalogued at MZFC; ENS (Eric N. Smith) to be catalogued at UTA; JAC (Jonathan A. Campbell) to be catalogued at UTA; JRV (Jacobo Reyes-Velasco) to be catalogued at UTA.

Museum acronyms throughout follow Sabaj-Pérez (2016). Representative specimens of snail-suckers and Geophis were examined in the following collections, in addition to specimens deposited in the collections reported above: the University of Kansas Natural History Collection (KU), Natural History Museum of Los Angeles County (LACM), Texas Cooperative Wildlife Collection (TCWC), University of Illinois Museum of Natural History (UIMNH). Specimen numbers for all material examined are provided in Appendix 1. We were not able to measure type specimens of some previously described taxa, so we used the measurements of the type specimens provided in the original descriptions and other published literature.

\section{Taxonomy}

We agree with Smith (1982) that the genus Sibon is a masculine noun so the specific epithet should also be masculine. We follow Kofron's (1980, 1985a, 1985b, $1987,1988,1990)$ proposal for the majority of recognized species, with the following differences. We recognize the Tropidodipsas fasciata species group as proposed by Kofron (1987); however, we recognize Tropidodipsas as distinct from Sibon following Wallach (1995). We do not consider Sibon anthracops to belong to Tropidodipsas based on the phylogenetic evidence presented by Sheehy (2013). We recognize Tropidodipsas guerreroensis as a separate species rather than a subspecies of $T$. fasciata (see below). Thus, we consider Tropidodipsas to contain the $T$. fasciata species group which consists of five species (T. fasciata, T. guerreroensis, T. philippii and the two species described below) as well as two un-assigned species which we have not been able to sample ( $T$. repleta and T. zweifeli) and T. fischeri which is tentatively retained in the genus pending more work (see below).

\section{Measurements and character states}

Our measurements and character states follow Kofron (1980) for all Dipsadidae and Downs (1967) for Geophis. Measurements and character states were taken from data published in Kofron's succession of work on Mexican Dipsadidae such as Tropidodipsas Kofron (1980), Dipsas gaigeae and D. brevifacies (Kofron 1982), T. fischeri species group (Kofron 1985a), Tropidodipsas (Kofron 1987), T. sartorii species group (Kofron 1988), S. dimidiatus (Kofron 1990) as well as Davis (1953) for T. guerreroensis. Some measurements and characters for Central and South American Dipsadidae were taken from Lotzkat et al. (2012) and Arteaga et al. (2018). Abbreviations used in the text and tables are as follows: snout-vent length (SVL), tail length (TL), total length (TotL), head length (HL), head width (HW), snout length (SL), eye diameter (ED), chinshield (CS).

Scale counts were performed with the aid of a dissecting microscope. Measurements were taken with a ruler or digital calipers (Truper ${ }^{\circledR}$, Mexico) under a dissecting microscope. Bilateral characters were scored on both left and right sides and given in that order, separated by a slash (/). Head length was measured from the tip of the snout to the posterior end of the parietals (following Peters 1964), head width was measured at the widest point of the head at the posterior part of the jaw. All scale dimensions were measured at their maximum.

To examine dentition characters, the maxilla and ectopterygoid were removed from the skull and cleansed in a dilute solution of Proteinase $\mathrm{K}$ for approximately one hour.

\section{DNA extraction and amplification}

We sequenced genetic data from two nuclear (DNAH3, NT3) and two mitochondrial (cytb, ND4) loci, and combined our data with previous studies of the group (Arteaga et al. 2018; Sheehy 2013).

We used $370 \mu \mathrm{L}$ of Monarch gDNA Tissue Lysis buffer (New England Biolabs T3011L) and $20 \mu \mathrm{L}$ of Proteinase $\mathrm{K}$ (New England Biolabs P8107S) to digest the tissue at $55^{\circ} \mathrm{C}$ overnight. We extracted whole genomic DNA from lysed samples using the Serapure bead extraction protocol of Rohland and Reich (2012) with modifications based on Glenn et al. (2019) for Sera-Mag SpeedBeads (Fisher Scientific 09-981-123).

We used polymerase chain reaction (PCR) to amplify two nuclear genes and two mitochondrial genes. The nuclear genes were $D N A H 3$ using DNAH3_f1 as the 
forward primer and DNAH3 r6 as the reverse primer (Townsend et al. 2008) and NT3 using NT3 F3 as the forward primer and NT3_R4 as the reverse primer (Noonan and Chippindale 2006). The mitochondrial genes were $c y t b$ using Gludg-L as the forward primer (Palumbi 1996) and ATRCB3 as the reverse primer (Harvey et al. 2000) and ND4 using ND4 as the forward primer and ND4_Leu as the reverse primer (Arevalo et al. 1994). All four loci were amplified using a standard PCR protocol: $95^{\circ} \mathrm{C}$ for 3 $\min 30 \mathrm{sec}, 35 \mathrm{cycles}$ of $95^{\circ} \mathrm{C}$ for $30 \mathrm{sec}, 51^{\circ} \mathrm{C}$ for $D N A H 3$ and NT3 and $53^{\circ} \mathrm{C}$ for $c y t b$ and ND4 for $30 \mathrm{sec}, 72^{\circ} \mathrm{C}$ for 1 min, followed by $15 \mathrm{~min}$ at $72^{\circ} \mathrm{C}$ and a final hold at $10^{\circ} \mathrm{C}$. All PCR reactions were $30 \mu \mathrm{L}$ and contained the following: $16.9 \mu \mathrm{L}$ of water, $3 \mu \mathrm{L}$ of $10 \mathrm{X}$ Reaction Buffer (New England Biolabs M0320L), $1.8 \mu \mathrm{L} \mathrm{MgCl}_{2}(25 \mathrm{mM}), 0.6$ $\mu \mathrm{L}$ dNTPs (2.5mM each; New England Biolabs N0446S), $0.3 \mu \mathrm{L}$ DMSO, $0.6 \mu \mathrm{L}$ of each primer $(10 \mu \mathrm{M}), 0.2 \mu \mathrm{L}$ of Taq DNA Polymerase (New England Biolabs M0320L), and $6 \mu \mathrm{L}$ of genomic DNA. PCR reactions were purified using $5 \mu \mathrm{L}$ of Quick Cip (New England Biolabs M0525S) and incubating at $37^{\circ} \mathrm{C}$ for $30 \mathrm{~min}$ and inactivating the enzymes at $80^{\circ} \mathrm{C}$ for $15 \mathrm{~min}$.

Sequencing was done in both directions using Eurofins Genomics LLC (Louisville, KY, USA). Forward and reverse reads were merged and trimmed in Geneious Prime v2020.2.1 (Biomatters Ltd., Auckland, NZ) and manually screened for errors and ambiguities. Heterozygous sites in nuclear genes were coded using International Union of Pure and Applied Chemistry (IUPAC) ambiguity codes. All sequences were deposited in GenBank. Information on all the new sequences as well as other sequences used in this study are found in Table 1.

\section{Molecular Analysis}

Alignments for each locus were performed in MAFFT version 7 (Katoh \& Standley 2013). We used Geneious v9.1.6 (Biomatters Ltd, Auckland, NZ) to manually trim any regions of poor alignment and to make sure that protein-coding genes were in the correct reading frame. We then concatenated all genes with the use of FASconCAT-G v1.04 (Kück and Longo 2014). Our concatenated dataset consisted of 3,248 bp, of which $1987 \mathrm{bp}$ correspond to two mitochondrial loci and $1261 \mathrm{bp}$ to two nuclear loci.

We chose the best-fit model of nucleotide evolution for each locus with the use of the Bayesian Information Criterion (BIC) in PartitionFinder v1.1.1 (Lanfear et al. 2012). Table 2 shows the best-fit model for each locus. We partitioned our dataset by locus and by codon position. We then performed Bayesian phylogenetic inference (BI) in Mr. Bayes v3.2.2 (Ronquist et al. 2012) on the CIPRES science gateway server (Miller et al. 2011).

Our Bayesian phylogenetic analysis consisted of four runs of 10 million generations, sampling every $1,000^{\text {th }}$ generation. Each run contained four chains, three heated and one cold. We checked for convergence between runs with the use of Tracer v1.6 (Rambaut et al. 2015) by visually inspecting overlap in likelihood and parameter estimates between runs, as well as effective sample sizes and potential scale reduction factor (PSRF) for each run. The individual runs had converged by 200,000 generations (based on the PSRF), so we conservatively discarded the first $25 \%$ of each run as burn-in. The runs were combined with the use of TreeAnnotator (Bouckaert et al. 2019) and visualized in FigTree v1.4.2 (Rambaut 2014).

Table 1. GenBank Numbers of sequences used in this study. New sequences are indicated in bold.

\begin{tabular}{|c|c|c|c|c|c|c|}
\hline Species & Locality & Specimen number & ND4 & cytb & NT3 & DNAH3 \\
\hline Chersodromus liebmanni & Mexico: Oaxaca & AMNO-2298 & JX398451 & JX398604 & JX398732 & JX293840 \\
\hline Dipsas andiana & Ecuador & JM-79 & JX398453 & JX398607 & JX398744 & $J \times 293843$ \\
\hline Dipsas articulata & Costa Rica & D-161 & JX398454 & - & JX398740 & - \\
\hline Dipsas bicolor & Costa Rica & ASL277 & JX398455 & - & JX398741 & $J \times 293844$ \\
\hline \multirow[t]{2}{*}{ Dipsas bobridgelyi } & Ecuador & MZUTI-5414 & - & МH374984 & - & - \\
\hline & Ecuador & MZUTI-5417 & - & MH374985 & - & - \\
\hline Dipsas catesby & Ecuador & UTAR-55974 & - & JX398458 & JX398610 & JX398743 \\
\hline \multirow[t]{3}{*}{ Dipsas gaigeae } & Mexico: Colima & JAC-28327 & JX398461 & JX398612 & - & $J \times 293849$ \\
\hline & Mexico: Colima & JAC-28587 & JX398462 & JX398613 & JX398735 & $J \times 293850$ \\
\hline & Mexico: Guerrero & JRV-30 & JX398464 & JX398614 & JX398738 & $J \times 293851$ \\
\hline Dipsas gracilis & Ecuador & UTAR-55943 & JX398466 & JX398616 & JX398747 & JX293853 \\
\hline Dipsas indica & Peru & KU-204908 & JX398468 & JX398618 & JX398734 & JX293854 \\
\hline \multirow[t]{2}{*}{ Dipsas klebbai } & Ecuador & QCAZ-12717 & - & МH375019 & - & - \\
\hline & Ecuador & QCAZ-12799 & - & MH374996 & - & - \\
\hline Dipsas mikanii & Brazil & CTMZ-495 & - & JX398693 & JX398816 & JX293896 \\
\hline Dipsas nicholsi & Panama & JM-812 & JX398469 & JX398619 & - & - \\
\hline Dipsas oswaldobaezi & Ecuador & QCAZ-10369 & - & МH374997 & - & - \\
\hline Dipsas pavonina & Brazil & LSUMZ-H13989 & JX398470 & JX398620 & JX398749 & $J \times 293855$ \\
\hline Dipsas peruana & Peru & LSUMZ-H1532 & JX398472 & JX398622 & JX398750 & JX293856 \\
\hline Dipsas petersi & Ecuador & JM-72 & JX398555 & JX398695 & JX398818 & $J \times 293898$ \\
\hline Dipsas pratti & Venezuela & MBUCV-6837 & JX398473 & JX398624 & JX398751 & - \\
\hline Dipsas temporalis & Panama & $J M-664$ & JX398476 & JX398626 & - & - \\
\hline Dipsas trinitatis & Trinidad & UWIZM.2011.20.25 & JX398479 & JX398629 & - & - \\
\hline Dipsas turgidus & Bolivia & LSUMZ-H6458 & JX398556 & JX398696 & JX398819 & JX293899 \\
\hline Dipsas variegata & Suriname & UTAR-15772 & JX398482 & JX398601 & JX398736 & $J \times 293858$ \\
\hline \multirow[t]{2}{*}{ Geophis bicolor } & Mexico: Jalisco & INIRENA-2793 & MZ287388 & MZ287374 & MZ287422 & - \\
\hline & Mexico: Michoacán & JAC-24684 & JX398487 & JX398637 & JX398759 & JX293862 \\
\hline
\end{tabular}




\begin{tabular}{|c|c|c|c|c|c|c|}
\hline Species & Locality & Specimen number & ND4 & cytb & NT3 & DNAH3 \\
\hline Geophis nigrocinctus & Mexico: Jalisco & JAC-30704 & JX398488 & $J \times 398638$ & - & - \\
\hline Geophis omiltemanus & Mexico: Guerrero & ENS-11496 & - & JX398639 & $J \times 398760$ & - \\
\hline Geophis tarascae & Mexico: Michoacán & JAC-24692 & JX398489 & JX398640 & JX398761 & $J \times 293870$ \\
\hline Ninia atrata & Colombia & MHUA-14152 & GQ334659 & GQ334553 & - & GQ334577 \\
\hline Ninia diademata & Guatemala & UTAR-42291 & - & JX398645 & JX398764 & $J \times 293864$ \\
\hline Sibon annulatus & CostaRica & D-167 & JX398501 & JX398652 & JX398772 & $J \times 293869$ \\
\hline Sibon anthracops & CostaRica & ASL-198 & JX398506 & JX398657 & JX398778 & $J \times 293872$ \\
\hline Sibon argus & Costa Rica & ASL-283 & JX398508 & JX398660 & JX398781 & $J \times 293878$ \\
\hline \multirow[t]{2}{*}{ Sibon bevridgelyi } & Ecuador & MZUTI-3269 & - & MH374962 & - & - \\
\hline & Ecuador & MZUTI-5416 & - & МH374963 & - & - \\
\hline Sibon carri & Guatemala & UTAR-45493 & JX398514 & $J \times 398665$ & JX398786 & $J \times 293876$ \\
\hline Sibon dimidiatus & CostaRica & B45-62 & JX398515 & $J \times 398666$ & JX398787 & $J \times 293877$ \\
\hline Sibon lamari & Costa Rica & No Number & $J \times 398520$ & JX398671 & JX398791 & JX293879 \\
\hline Sibon longifrenis & Costa Rica & ASL-220 & JX398521 & JX398672 & JX398792 & $J \times 293880$ \\
\hline Sibon manzanaresi & Honduras & USNM-570455 & JX398524 & JX398685 & JX398795 & $J \times 293883$ \\
\hline Sibon merendonensis & Guatemala & MVZ-263880 & JX398526 & JX398675 & JX398797 & $J \times 293884$ \\
\hline Sibon miskitus & Honduras & USNM-570454 & JX398528 & JX398677 & JX398799 & $J \times 293885$ \\
\hline \multirow[t]{2}{*}{ Sibon nebulatus } & Mexico: Chiapas & INIRENA-2788 & MZ287387 & MZ287377 & Pending & - \\
\hline & Guatemala & UTAR-42431 & JX398549 & JX398690 & JX398812 & $J \times 293891$ \\
\hline Sibon perissostichon & Panama & SMF-88716 & JX398552 & JX398688 & JX398814 & $J \times 293888$ \\
\hline Geophis sanniolus new comb. & Mexico: Yucatan & JAC-24409 & JX398553 & JX398692 & JX398815 & JX293895 \\
\hline \multirow{2}{*}{$\begin{array}{l}\text { Geophis annuliferaus new } \\
\text { comb. }\end{array}$} & Mexico: Guerrero & JAC-27792 & JX398559 & JX398699 & - & JX293914 \\
\hline & Mexico: Colima & JAC-30143 & JX398561 & JX398701 & - & - \\
\hline \multirow{2}{*}{ Tropidodipsas cf. fasciata } & Mexico: Yucatan & INIRENA-2780 & - & MZ287385 & - & - \\
\hline & Mexico: Tamaulipas & CIG-0819 & - & - & MZ287421 & MZ287402 \\
\hline \multirow[t]{2}{*}{ Tropidodipsas fasciata } & Mexico: Oaxaca & JAC-22920 & - & JX398702 & - & - \\
\hline & Mexico: Oaxaca & JAC-30740 & $J \times 398580$ & $J \times 398713$ & - & - \\
\hline \multirow[t]{3}{*}{ Tropidodipsas fischeri } & Mexico: Chiapas & CHFCB-0332 & MZ287396 & MZ287378 & - & - \\
\hline & Mexico: Chiapas & CHFCB-0335 & MZ287397 & MZ287379 & - & - \\
\hline & Mexico: Chiapas & CHFCB-0352 & MZ287398 & MZ287380 & - & - \\
\hline \multirow[t]{4}{*}{ Tropidodipsas guerreroensis } & Mexico: Guerrero & INIRENA-2781 & MZ287395 & MZ287381 & MZ287420 & MZ287403 \\
\hline & Mexico: Oaxaca & JAC-22545 & - & - & JX398828 & - \\
\hline & Mexico: Oaxaca & JAC-24267 & JX398594 & JX398724 & JX398839 & JX293919 \\
\hline & Mexico: Guerrero & JRV-31 & JX398562 & - & - & - \\
\hline $\begin{array}{l}\text { Tropidodipsas guerreroensis } \\
\text { (As T.philippi) }\end{array}$ & Mexico: Guerrero & $J A C-27750$ & JX398571 & $J \times 398711$ & - & $J \times 293908$ \\
\hline \multirow{6}{*}{$\begin{array}{l}\text { Tropidodipsas papavericola } \\
\text { sp. nov. }\end{array}$} & Mexico: Guerrero & INIRENA-2805 (paratype) & MZ287392 & MZ287382 & MZ287418 & MZ287400 \\
\hline & Mexico: Guerrero & INIRENA-2801 (holotype) & - & MZ287383 & MZ287419 & - \\
\hline & Mexico: Guerrero & INIRENA-2802 (paratype) & MZ287391 & MZ287384 & MZ287417 & MZ287401 \\
\hline & Mexico: Guerrero & INIRENA-2803 (paratype) & MZ287393 & - & - & - \\
\hline & Mexico: Guerrero & IDF-89 & JX398558 & JX398698 & JX398824 & $J \times 293902$ \\
\hline & Mexico: Guerrero & UTAR-51854 & JX398550 & - & JX398813 & - \\
\hline \multirow[t]{5}{*}{ Tropidodipsas philippii } & Mexico: Jalisco & ENS-11639 & JX398569 & - & - & $J \times 293907$ \\
\hline & Mexico: Nayarit & JAC-24811 & JX398570 & JX398710 & JX398826 & - \\
\hline & Mexico: Michoacán & JAC-27923 & JX398572 & JX398712 & - & $J \times 293909$ \\
\hline & Mexico: Colima & JAC-28262 & JX398573 & - & - & $J \times 293910$ \\
\hline & Mexico: Sinaloa & JAC-30601 & JX398577 & - & - & - \\
\hline \multirow[t]{4}{*}{ Geophis sartorii new comb. } & Mexico: San Luis Potosí & INIRENA-2783 & MZ287390 & MZ287375 & MZ287412 & MZ287406 \\
\hline & Mexico: San Luis Potosí & INIRENA-2784 & MZ287389 & MZ287376 & MZ287410 & - \\
\hline & Mexico: San Luis Potosí & INIRENA-2785 & - & - & MZ287411 & MZ287408 \\
\hline & Unknown & JAC-30401 & JX398583 & JX398716 & - & - \\
\hline \multirow{2}{*}{$\begin{array}{l}\text { Tropidodipsas tricolor sp. } \\
\text { nov. }\end{array}$} & Mexico: Oaxaca & INIRENA-2799 (paratype) & - & - & MZ287416 & - \\
\hline & Mexico: Guerrero & INIRENA-2800 (holotype) & MZ287394 & MZ287386 & MZ287415 & MZ287404 \\
\hline
\end{tabular}

Table 2. Best fit models of nucleotide evolution for each locus.

\begin{tabular}{lll}
\hline Partition & Partition set & Best-Fit Model \\
\hline 1 & cytb (first codon) & GTR + I + gamma \\
2 & cytb (second codon) & HKY + I + gamma \\
3 & cytb (third codon) & GTR + gamma \\
4 & DNAH3 (first codon) & JC \\
5 & DNAH3 (second codon) & JC + gamma \\
6 & DNAH3 (third codon) & HKY + gamma \\
7 & ND4 (first codon) & GTR + I + gamma \\
8 & ND4 (second codon) & HKY + gamma \\
9 & ND4 (third codon) & GTR + gamma \\
10 & NT3 (first codon) & HKY + gamma gamma \\
11 & NT3 (second codon) & HKY + gamma \\
12 & NT3 (third codon) & HKY + gamma \\
13 & tRNA & \\
\hline
\end{tabular}


We consider a clade as highly supported if the posterior support value was greater than 0.95 .

Additionally, we calculated uncorrected p-distances for the mitochondrial gene Cytochrome B (cytb) in the program MEGA X (Kumar et al. 2018). We calculated genetic distances of $c y t b$ once we completed the concatenated data set.

\section{Results}

\section{Molecular phylogenetic results}

We used a total of 79 individuals in our molecular phylogeny, including 76 snail-sucker individuals as well as three outgroup taxa. Of the individuals used, 18 specimens were novel sequences obtained by us, representing 9 taxa. As shown by previous studies (Sheehy 2013; Arteaga et al. 2018), the three currently recognized genera of snail-suckers form a monophyletic group, which also received high support in our analysis (Posterior Probability $[\mathrm{pp}]=1)$ (Fig. 6).

Our results recovered a monophyletic Dipsas, including members previously allocated to Sibynomorphus, a South American genus previously synonymized with Dipsas (Arteaga et al. 2018). The only exception was D. gaigeae, a species restricted to western Mexico. This species and Tropidodipsas fischeri each formed monophyletic, highly supported, independent clades but their relationships with the remaining species of snail-suckers are poorly supported and remain ambiguous as they form a polytomy in a clade containing Tropidodipsas, Sibon and Geophis. Combined, these results were consistent with those reported by Sheehy (2013). We also recovered a strongly supported clade containing the majority of species of Tropidodipsas. This clade consisted of two main groups. The first one included both taxa from southern Mexico described herein, as well as an individual of T. cf. fasciata from Yucatan (with low node support, $\mathrm{pp}=0.67$ ). The other group in Tropidodipsas consisted of an individual of $T$. $c f$. fasciata from Tamaulipas (Fig. 7A), T. fasciata from Oaxaca, which was sister to T. guerreroensis $+T$. philippii (also with low node support, $\mathrm{pp}=0.65$ ). The fact that the three geographically distinct populations of $T$. fasciata fall in different positions in the tree suggest that this taxon needs further study and better sampling. Unfortunately, more material is currently unavailable, as most $T$. fasciata samples are from the Oaxaca (Isthmus of Tehuantepec) population. The type locality of $T$. fasciata has not been delimited beyond "Mexico" and thus it would be difficult to assign a specific clade to that name. Our suggestion is that a more detailed study of the $T$. fasciata species complex should be undertaken in the future.

The remaining snail-suckers grouped into two clades. The first clade is composed of multiple species currently allocated to three different genera: Sibon sanniolus from southeastern Mexico; the species Tropidodipsas annulifera and T. sartorii; multiple members of the genus Geophis. This clade had moderate support $(\mathrm{pp}=0.88)$ and the node with $T$. sartorii and T. annulifera plus several Geophis was recovered with more robust support $(\mathrm{pp}=0.93)$. From here on we refer to all these species as Geophis (see below). Several of the internal nodes were recovered as weakly supported ( $\mathrm{pp}<0.90$ ). These results are similar to what was presented by Sheehy (2013) and Arteaga et al. (2018).

The last clade consisted of the majority of species in the genus Sibon, with the exception of $S$. sanniolus. The majority of nodes in this clade were recovered as highly supported $(\mathrm{pp}>0.95)$. These results were in agreement with Sheehy (2013).

Our phylogenetic results support the novelty of the two species described herein, as we show that they are not conspecific with any previously described taxa and form monophyletic clades. Furthermore, our results suggest that these two new species are each other's closest relative, and together with a sample of $T$. cf. fasciata from Yucatan they form a sister clade to the clade containing $T$. cf. fasciata, T. philippi and T. guerreroensis. Our analysis supports the validity of $T$. guerreroensis as a species as originally described, not a subspecies of T. fasciata, as it is more closely related to T. philippi and a sample of $T$. $c f$. fasciata from Tamaulipas (CIG 819) than the T. fasciata from nearby Oaxaca (see below).

\section{Systematic accounts}

\section{Tropidodipsas tricolor sp. nov.}

http://zoobank.org/54130B5D-9C0D-4C8C-8417-00EB50E65216

Figs 1-2

Proposed standard English name: Tricolor Snailsucker

Proposed standard Spanish name: Caracolera tricolor

Holotype. (Fig. 1) INIRENA 2800 (original field number CIG 1837). Juvenile male, collected at $1.5 \mathrm{~km}$ east of Río Verde, Municipio de Atoyac de Álvarez, $\left(17.3131^{\circ},-100.1969^{\circ}\right.$, datum=WGS84, $971 \mathrm{~m}$ a.s.1.), Guerrero, Mexico (Fig. 3A) on August 14 $4^{\text {th }}, 2020$ by Miguel A. Peñaloza-Montaño, Jason M. Jones and Jacobo Reyes-Velasco.

Paratypes. (2) (Figs. 2C-D) INIRENA 2799 (original field number CIG 1596). Adult of unknown sex, DOR, collected at $26 \mathrm{~km} \mathrm{~N}$ of Putla Villa de Guerrero, on Putla Villa de Guerrero - Oaxaca Hwy., Municipality of Putla de Guerrero $\left(17.1494^{\circ},-97.8709^{\circ}\right.$, datum=WGS84, $1785 \mathrm{~m}$ a.s.1.), Oaxaca, Mexico, on September $4^{\text {th }}, 2019$ by Christoph I. Grünwald, Christopher M. Rodriguez and Carmen Mendoza-Portilla; INIRENA 2798 (original field number CIG 1863). Adult female, DOR, collected at $4.5 \mathrm{~km} \mathrm{NW}$ of Mixtecapa, on the road to Malinaltepec, Municipio de Malinaltepec, $\left(17.2539^{\circ},-98.6406^{\circ}\right.$, datum $=$ WGS84, 1815 m a.s.1.), Guerrero, Mexico on October $21^{\text {st }}, 2020$ by Tziuhtécatl Sánchez-Luna.

Diagnosis. Tropidodipsas tricolor sp. nov. is placed in the genus Tropidodipsas based on phylogenetic evidence 
(Fig. 6). It belongs to the Tropidodipsas fasciata group as defined by Kofron (1987) based on possessing a laterally compressed body, head distinctly wider than neck, protruding eyes of moderate to large diameter, vertebral and paravertebral scales not wider than other dorsal scales, 17 maxillary teeth, 18 dentary teeth, postmental scale absent. The species differs from all described species of Tropidodipsas based on the following combination of characters: (1) $15 / 15 / 15$ rows of smooth dorsal scales with no enlarged vertebral row; (2) prefrontal broader than long, entering the orbit; (3) loreal square, equally long as high, not entering the orbit; (4) 183 ventral scales in males, 183 in females; (5) 78-79 divided subcaudals in males and 79 in females; (6) 19-22 reddish orange, light-edged bands on body, most with dark brown or black medial stippling, giving the snake a "tricolor" effect; 8 pale bands on tail; (7) ground color black or nearly so; (8) iris chocolate brown; (9) TL/SVL 0.31 in one male specimen, and 0.30 in one female specimen.

Comparisons. Tropidodipsas tricolor sp. nov. is most similar to T. philippii, T. fasciata, T. guerreroensis and the new species described below. It is the only species of snail-sucker in Mexico with a tricolor pattern, although similar patterns exist in Central American (e.g., Sibon anthracops) and South American (e.g., Dipsas bobridgelyi) snail-suckers. It is distinguished from other Mexican snail-suckers such as the Geophis chalybeus species group, the Geophis omiltemanus species group, G. sartorii new comb., G. annuliferus new comb., Tropidodipsas fischeri (Fig. 9C,D), S. carri, G. sanniolus new comb. and $S$. linearis by the laterally compressed body shape and the tri-colored pattern. Further, it differs from other snail-sucker species (character states in parenthesis) as follows: It differs from $S$. anthracops by possessing 15 scale rows at midbody (vs. 13), possessing a prefrontal that enters the orbit (vs. prefrontal does not enter orbit), loreal not entering the orbit (vs. loreal enters orbit). It may be distinguished from $S$. dimidiatus by its noticeably different tricolor banded dorsal coloration (vs. brown snake with dark blotches, spots or an undulating stripe) and by lacking a post-mental scale (vs. usually one or two post-mental scales present) and by possessing less than 80 subcaudals in males (vs. 96-144). It is distinguished from Sibon nebulatus (Fig. 9A,B) by possessing tricolor body bands (vs. a nebulated black, grey and white pattern with no red outlines in the pale bands), and by vertebral scales not enlarged (vs. row of vertebral scales 1.25-1.35 times larger than other dorsal scales).

This species differs from Dipsas gaigeae by having 15 dorsal scale rows at mid-body (vs. 13), possessing more than 180 ventral scales (vs. 155-169) and a loreal that does not enter orbit (vs. loreal entering orbit). Distinct from $D$. brevifacies by possessing more than 180 ventrals (vs. 162-180), always possessing the prefrontal in contact with orbit (vs. usually not), never possessing a loreal in contact with orbit (vs. usually in contact), usually possessing $1+2$ temporals (vs. usually $2+3$ ), and usually possessing one pair of infralabials in contact after the mental (vs. usually two pairs of infralabials in contact after the mental).

Within Tropidodipsas, T. tricolor sp. nov. differs from T. fasciata and T. guerreroensis by possessing 15 smooth dorsal scale rows (vs. 17 keeled scale rows) and by prefrontal entering orbit (vs. not entering orbit). It differs from the new species described below (Tropidodipsas papavericola sp. nov.; see below) by tricolor outline in pale dorsal bands (vs. unicolor pales body bands), 19-22 reddish orange body bands (vs. 25-33 pale body bands), by possessing a prefrontal which enters the orbit (vs. prefrontal not entering orbit), by possessing 78-79 subcaudal scales in males (vs. 69-76), by possessing one preocular (vs. two), by possessing 2-3 postoculars (vs. 1-2), 7-8 supralabials (vs. 5-7), 8-9 infralabials (vs. 6-7), eye-head length ratio $25 \%$ (vs. $17-21 \%$ ), by pale throat coloration with black stippling concentrated toward anterior portion and a black mental (vs. pale throat coloration with random dark spots not concentrated in any specific region and a black and white mental), and a narrower head with less protruding eyes (vs. head noticeably wider than neck and eyes strongly protruberant). It differs from T. philippii (Fig. 8C,D) by presenting one preocular (vs. 2-3), prefrontal entering orbit (vs. not entering orbit), supralabials 7-8 (vs. 6-7), 3 gular scales (vs. 5), a longer tail which is $30-31 \%$ of SVL in males (vs. $25-29 \%$ in males), consistently 19-21 pale body bands (vs. highly variable, from 9-44 according to Kofron $(1980,1987)$ but usually $11-21$, according to our data $(n=13)$, and eyehead length ratio of $25 \%$ (vs. $15-23 \%$ ).

Genetic divergence in a 1,072-bp fragment of mitochondrial cytb gene between T. tricolor sp. nov. and $T$. papavericola sp. nov. is $13-14 \%$; between $T$. tricolor $\mathrm{sp}$. nov. and geographically proximate $T$. fasciata, $14-15 \%$; between $T$. tricolor sp. nov. and $T$. guerreroensis, 14 16\%; and between T. tricolor sp. nov. and geographically proximate T. philippii, 15-16\%.

Description of holotype. (Fig. 1) INIRENA 2800. Juvenile male. SVL $210 \mathrm{~mm}$; TL $67 \mathrm{~mm}$; TotL $277 \mathrm{~mm}$. HL $8.5 \mathrm{~mm}$ (from tip to posterior border of parietal) and $7.7 \mathrm{~mm}$ (from snout to posterior commissure of mouth); HW $5.0 \mathrm{~mm}$, head distinct from body, approximately 2 times wider than neck. Snout short, blunt, SL $2.7 \mathrm{~mm}$, contained 3.1 times in the HL, rounded in dorsal and lateral profile. Loreal region tall, canthus rostralis rounded. Rostral 1.4 times as broad as high $(2.0 \mathrm{~mm}$ broad, 1.4 $\mathrm{mm}$ high); internasals broader than long (1.0 $\mathrm{mm}$ length, $1.6 \mathrm{~mm}$ width), rounded anteriorly, in lateral contact with anterior and posterior nasals; prefrontals relatively large, broader than long (1.7 mm length, $2.0 \mathrm{~mm}$ width), nearly rectangular, with posterior edge of scale pointed at supraocular and frontal suture, in median contact with each other and in lateral contact with postnasal, loreal, preocular (lower) and orbit; frontal 1.1 times longer than broad (2.8 $\mathrm{mm}$ long, $2.4 \mathrm{~mm}$ broad), pentagonal with angular tip posteriorly, in contact with prefrontals, supraoculars and parietals. One moderately large preocular on each side. Single supraocular moderate, in contact with pre- 


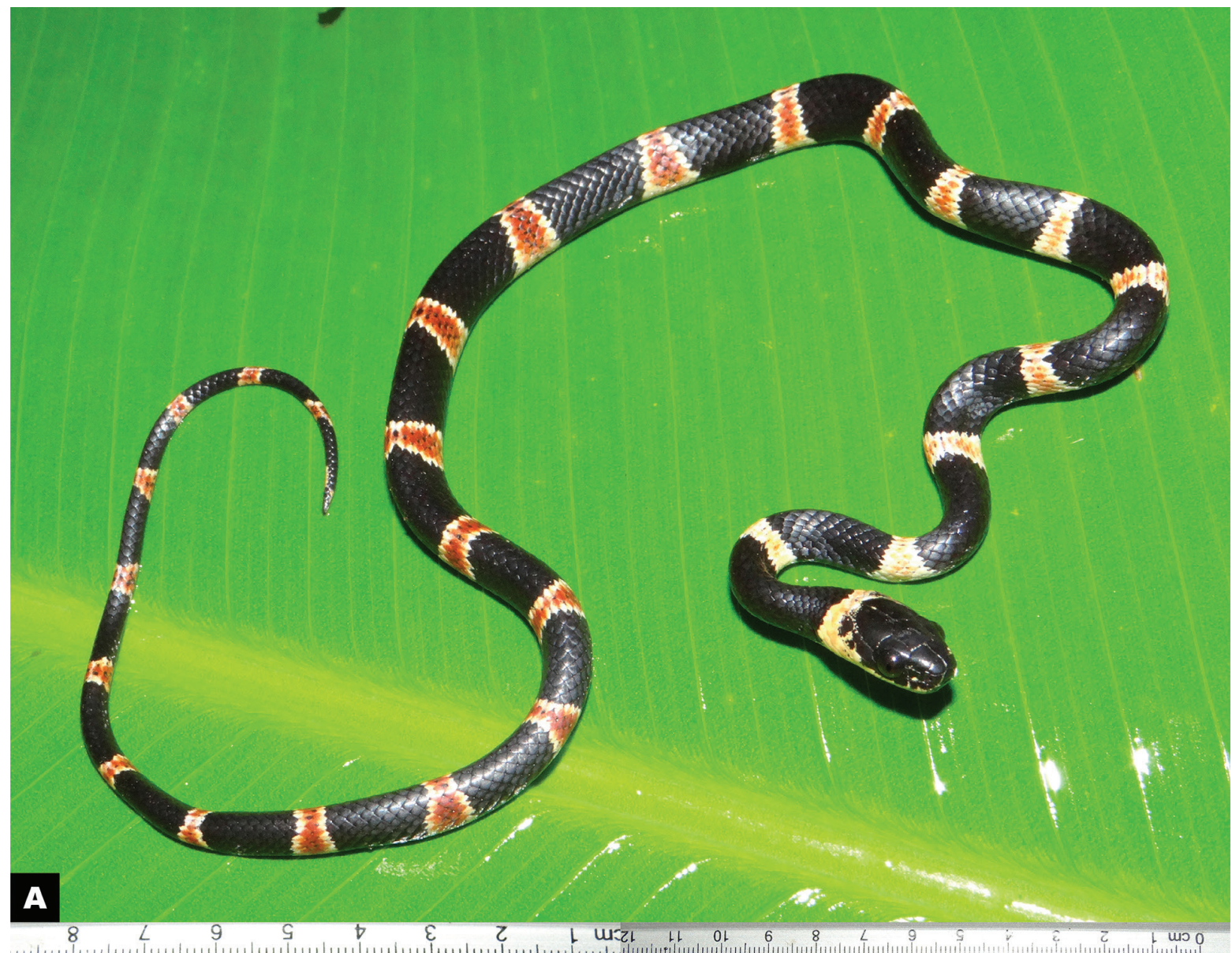

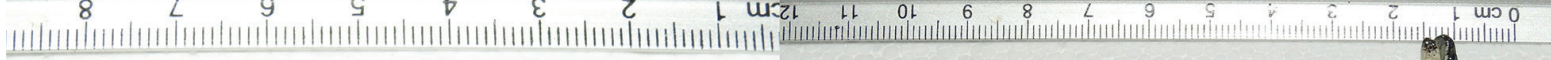

$\mathbf{B}$
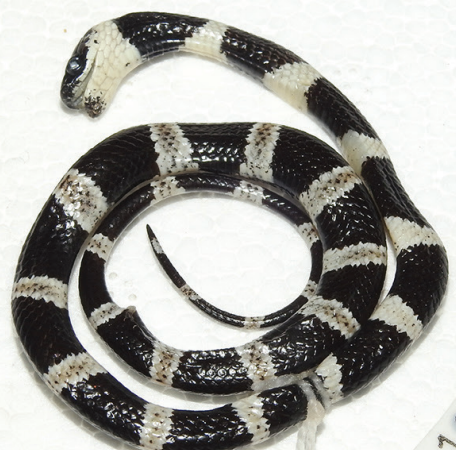

3

प ¿ wo

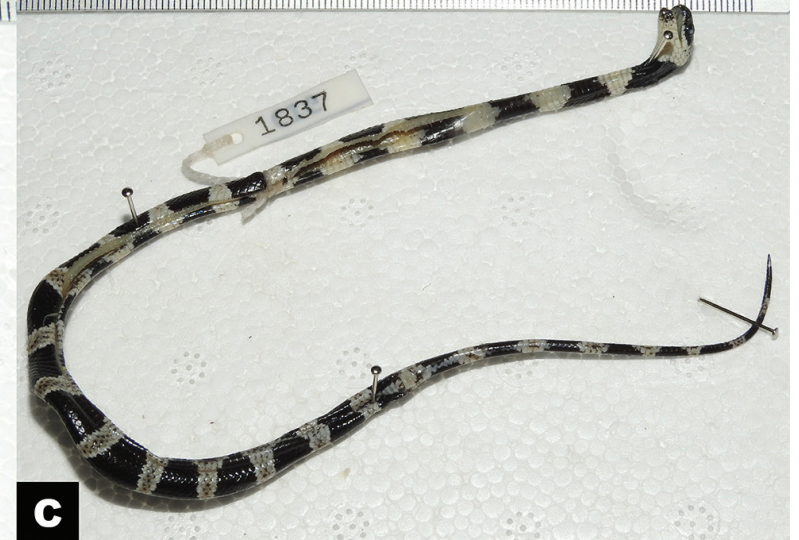

C
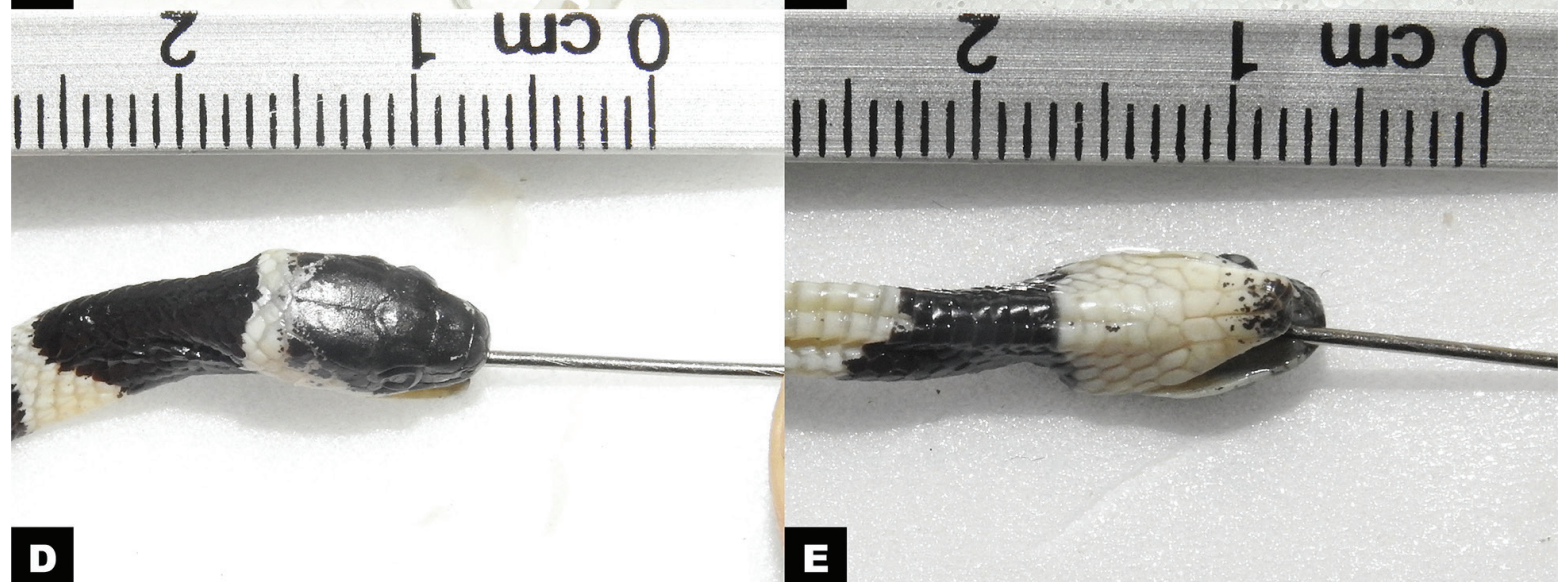

Figure 1. Tropidodipsas tricolor sp. nov. Holotype (INIRENA 2800). Holotype (INIRENA 2800) in life (A); Ventral aspect of Holotype (INIRENA 2800) in preservative (B,E); Dorsal aspect of Holotype (INIRENA 2800) in preservative. 


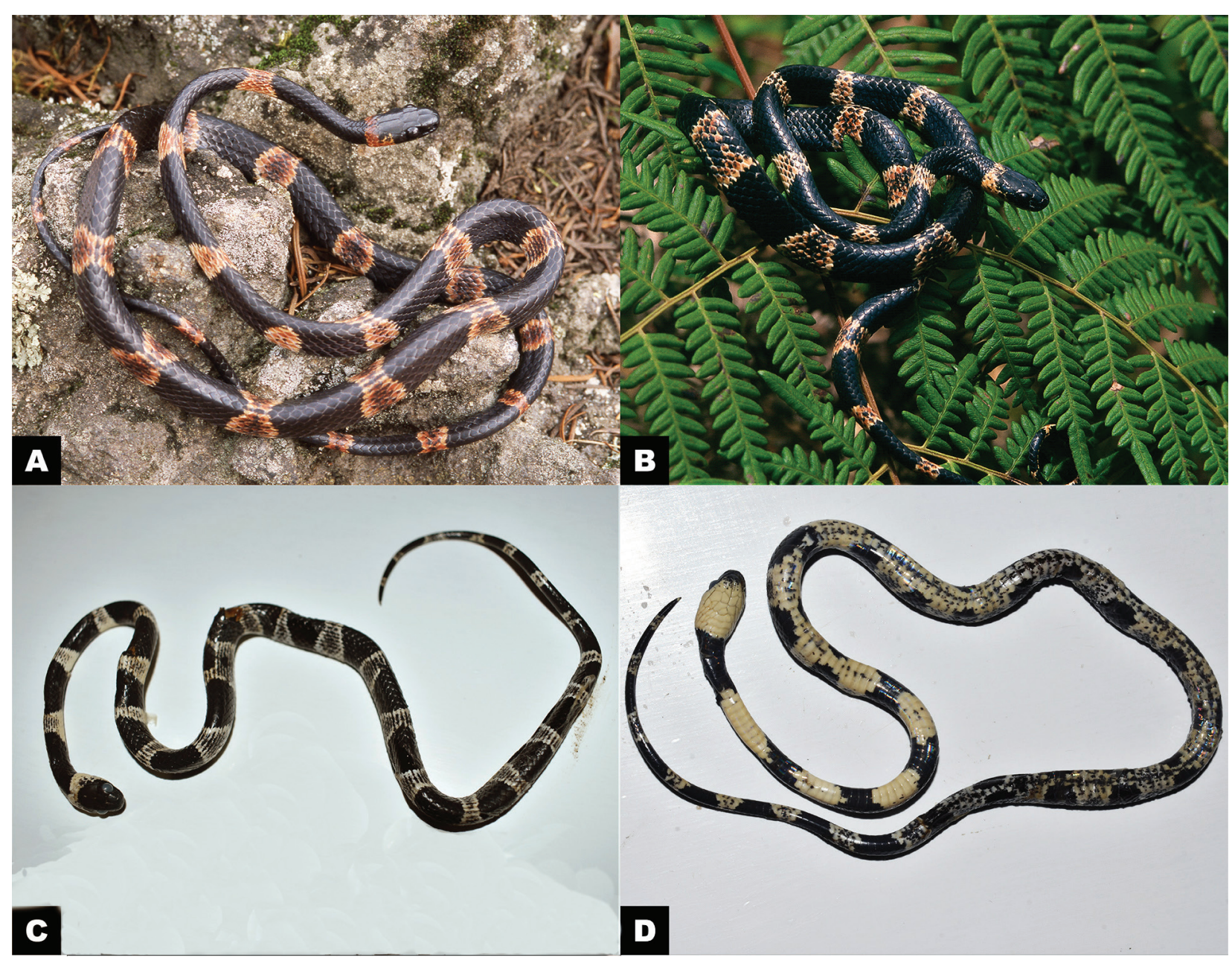

Figure 2. Tropidodipsas tricolor sp. nov. Variation. Female from Municipio de Leonardo Bravo, Guerrero (A); Male from Municipio de Leonardo Bravo, Guerrero (B); Photos A-B by Peter Heimes. Female (INIRENA 2798) from Municipio de Malinaltepec, Guerrero (C-D).

frontal, frontal, parietal, and upper postocular. Two moderately large postoculars on each side, lower one slightly larger than upper. Parietal 1.1 times as long as wide(4.3 $\mathrm{mm}$ long, $3.9 \mathrm{~mm}$ wide), the length of parietal $86 \%$ of $\mathrm{HL}$, the common suture between parietals $3.6 \mathrm{~mm}, 1.3$ times longer than frontal. Nasal divided, prenasal slightly taller than postnasal, with combined length of both nasals $(1.8 \mathrm{~mm})$ longer than loreal. Loreal small and almost square, $0.9 \mathrm{~mm}$ long, 1.0 high on left side, $1.0 \mathrm{~mm}$ long, $1.0 \mathrm{~mm}$ high on right side, and neither reaching orbit. Eye moderately large, $2.1 \mathrm{~mm}, 25 \%$ of HL. Supralabials $8 / 7$. On the left, first and second supralabials in contact with nasals, second, third and fourth in contact with loreal, fifth and six entering orbit, and seventh largest and in contact with lower postocular and two temporals. On the right, first and second in contact with nasals, second and third in contact with loreal, fourth and fifth entering orbit, and sixth largest and in contact with lower postocular, and two temporals. Temporals $1+2$ on both sides. Five nuchal scales in contact with parietals.

Mental 2.1 times as broad as long (1.5 mm broad, 0.7 $\mathrm{mm}$ long), flat anteriorly, rounded posteriorly with posterior edge coming to a slight point at the suture of the first infralabials, separated from the anterior chinshields by the enlarged first pair of infralabials which are in contact with each other. Infralabials 8 on both sides, $1-5$ in contact with anterior chinshields and 5-6 in contact with posterior chinshields, sixth infralabial is largest. Anterior chinshields elongated, much longer than wide, left chinshield $2.4 \mathrm{~mm}$ long and $0.9 \mathrm{~mm}$ wide (2.7 times as long as wide) and right anterior chinshield $2.6 \mathrm{~mm}$ long and $1.0 \mathrm{~mm}$ wide (2.6 times as long as wide). Left posterior chinshield $1.9 \mathrm{~mm}$ long and $1.1 \mathrm{~mm}$ wide (1.7 times as long as wide) and right posterior chinshield $1.8 \mathrm{~mm}$ long and $1.1 \mathrm{~mm}$ wide (1.6 times as long as wide). Three gular scales. Infralabials and scales in the chin region smooth. Distinct gular fold present, starting on the first ventral scale and running posteriorly to the twentieth ventral scale, then fading out by the twenty-fifth ventral scale. Dorsal scales in 15-15-15 rows, smooth throughout; apical pits not evident. Ventrals 183; anal plate single; subcaudal scales paired, 79 on both sides. Body shape laterally compressed. Pupil elliptical.

Coloration in life of the holotype (Fig. 1A). Dorsal coloration of head, body and tail black with 19 reddish orange, light-edged bands on body (not counting nuchal 


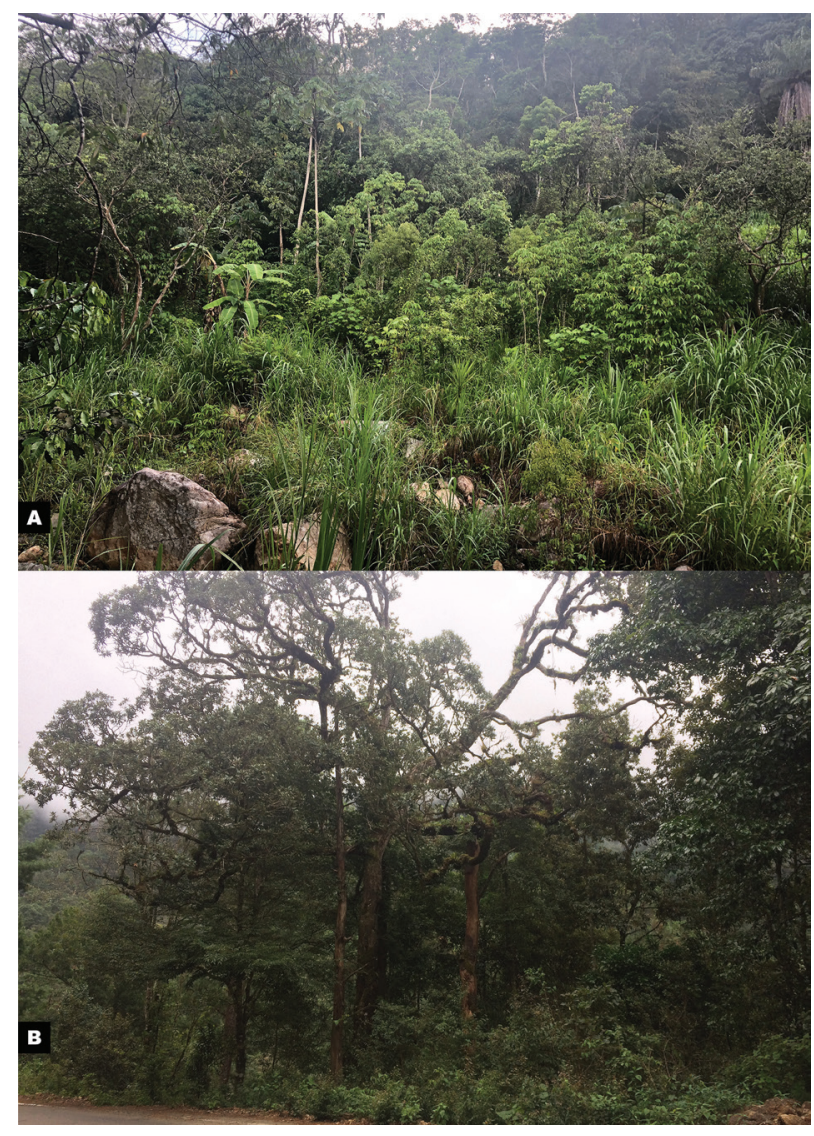

Figure 3. Habitat at the type locality of Tropidodipsas tricolor sp. nov. near Río Verde, Municipio de Atoyac de Álvarez, Guerrero (A); Habitat at the type locality of Tropidodipsas papavericola sp. nov. above Nuevo Delhi, Municipio de Atoyac de Álvarez, Guerrero (B).

band) and 9 bands on tail; red-orange color faded on four anteriormost bands. Nuchal band cream and involving latter fifth portion of the parietals and the anterior two and part of the third dorsal scale rows. Body bands 9-19 and all tail bands exhibit scattered dark stippling. The entire snake has a "tricolor" appearance. Pale bands on body and tail $2-4$ scale rows long $($ mean $=3)$ and wider on the lateral surfaces due to the increased scale size. Head coloration predominately black on dorsal surface and pale cream ventrally. The pale nuchal coloration extends forward onto posterior part of the parietals, and beneath the temporals onto the supralabials. Anterior supralabial black, the others bicolor, posterior supralabial predominately cream on both sides but with black flecking in the middle. Dark body color almost complete ventrally, occasionally interrupted mid-ventrally by a pale line. Light dorsal bands are complete ventrally but with dark flecking towards posterior part of body. Reddish orange coloration of dorsal bands does not continue onto the venter. Anal plate bicolored, black on the margins and pale cream in the middle. First dark band on tail interrupted mid-ventrally by pale cream coloration, the other dark and pale bands on tail complete ventrally. Tail tip black above, pale orange below. Pupil pale gray, iris chocolate brown in life.
Coloration in preservative of the holotype (Figs 1BE). General coloration tricolor. Reddish orange wedgeshaped markings have turned pale brown; the pale cream and orangish bands faded to white.

Variation. Meristic variation of the three available specimens is given in Table 3. One paratype (INIRENA 2798) possesses a tiny second preocular above the large lower preocular on both sides. This small scale does not prevent the prefrontal from entering the orbit as in the other specimens and may be a division of the lower preocular.

Two individuals were photographed by Peter Heimes in Guerrero in 2007. While these individuals were not collected or examined in detail, they are likely of this species. As we lack photos of variation of this new species in life, we have included photos of these two individuals which most probably belong to this species (Fig. 2A,B).

Dentition. One paratype (INIRENA 2798) has 17 maxillary teeth (including three empty sockets) on the right side. The same specimen had 18 dentary teeth (including one empty socket) on the right side.

Distribution, habitat and ecology. This species appears to be restricted to moderate elevations in Sierra Madre del Sur from central Guerrero to western Oaxaca (Fig. 10). Habitats include cloud forest, mesic pine-oak woodland, tropical evergreen forest, tropical semi-deciduous forest and combinations of those assemblages (Brown et al. 2007). Known from 700-2200 m a.s.l., though most localities are from 1700-2200 m a.s.l. with the exception of the Sierra de Atoyac where it has been found at 700-1000 $\mathrm{m}$ a.s.l. in mesic tropical evergreen forest (Fig. 3A). Specimens were found at night on low or medium $(1.5-3.0 \mathrm{~m})$ vegetation, or dead on the road.

Etymology. The specific epithet tricolor refers to the tricolor pattern of the black dorsal coloration interspersed by light dorsal bands of cream and reddish orange.

\section{Tropidodipsas papavericola sp. nov.}

http://zoobank.org/6D7EA79C-98E3-4287-92A9-E81C1831D6CA

Figs. 4-5

Proposed standard English name: Poppyfield Snailsucker Proposed standard Spanish name: Caracolera amapolera

Paratypes/ (5) (Fig. 5) INIRENA 2802 (original field number CIG 1496, Fig. 5C). Sub-adult male, collected AOR $18.1 \mathrm{~km} \mathrm{~S}$ of Puerto del Gallo on road from Nuevo Dehli to Puerto del Gallo, Municipio de Atoyac de Álvarez $\left(17.4342^{\circ},-100.191^{\circ}\right.$, datum=WGS84, $1654 \mathrm{~m}$ a.s.1.), Guerrero, Mexico on June 29 ${ }^{\text {th }}, 2019$ by Christoph I. Grünwald, Miguel A. Peñaloza-Montaño, Eduardo Y. Barrera-Nava, Karen I. Morales-Flores and Janelle Morales-Flores. INIRENA 2803 (original field number CIG 1502). Sub-adult male collected DOR at $5 \mathrm{~km} \mathrm{~S}$ of La Laguna, on road from San Luis La Loma to Bajitos de la Laguna, Municipio de Técpan de Galeana (17.5137 $-100.7737^{\circ}$, datum $=$ WGS84, $1686 \mathrm{~m}$ a.s.1.), Guerrero, Mexico on June $29^{\text {th }}, 2019$ by Jason M. Jones and Carlos Montaño-Ruvalcaba. INIRENA 2804 (original field 
number CIG 1632, Figs 5A-B). Adult male, collected at Bajitos de la Laguna, Municipio de Técpan de Galeana, Guerrero, Mexico on October 30 ${ }^{\text {th }}, 2019$ and retrieved by Alejandro Lara and donated to Jason M. Jones. INIRENA 2805 (original field number CIG 1457). Sub-adult male, collected at Jaguar Research Facility, Municipio de Técpan de Galeana, Guerrero, Mexico on June 10 $0^{\text {th }}, 2019$ by Miguel A. Peñaloza-Montaño and Eduardo Y. Barrera-Nava. INIRENA 2810 (JRV 0362, Fig. 2D). Juvenile male, collected DOR at $4.2 \mathrm{~km} \mathrm{~S}$ of La Laguna, on San Luis San Pedro - La Laguna Rd., Municipio de Técpan de Galeana $\left(17.5173^{\circ},-100.7715^{\circ}\right.$, datum=WGS84, $1620 \mathrm{~m}$ a.s.1.), Guerrero, Mexico on July $17^{\text {th }}, 2020$ by Jason M. Jones.

Diagnosis. Tropidodipsas papavericola $\mathrm{sp}$. nov. is placed in the genus Tropidodipsas based on phylogenetic evidence (Fig. 6). It belongs to the Tropidodipsas fasciata group as defined by Kofron (1987) based on possessing a laterally compressed body, head distinctly wider than neck, protruding eyes of moderate to large diameter, vertebral and paravertebral scales not wider than other dorsal scales, 17 maxillary teeth, 22 dentary teeth, postmental scale absent. The species differs from all described species of Tropidodipsas recognized herein based on the following combination of characters: (1) 15/15/15 rows of smooth dorsal scales with no enlarged vertebral row; (2) prefrontal broader than long, not entering orbit; (3) loreal almost square, slightly longer than broad, not entering orbit; (4) 179-189 ventral scales in males, unknown in females; (5) 69-76 divided subcaudals in males, unknown in females; (6) 25-34 pale bands on body and 10-16 pale bands on tail; (7) 26-36 dark bands on body and 10-16 on tail, irregular with faded pale centers in adult individuals; (8) TL/SVL 0.30-0.35 in males, unknown in females; (9) iris dark chocolate-gray in life.

Comparisons. Tropidodipsas papavericola sp. nov. is most similar to T. philippii, T. fasciata, T. guerreroensis and T. tricolor sp. nov. It is the only species of Tropidodipsas in Mexico with a nebulated pattern of obscured body rings, although the nearly sympatric Sibon nebulatus exhibits a similar pattern as do several species of snail-suckers in northwestern South America (Arteaga et al. 2018). It is distinguished from other Mexican snail-suckers such as the Geophis chalybeus species group, the Geophis omiltemanus species group, G. sartorii new comb., G. annuliferus new comb., Tropidodipsas fischeri (Fig. 9C,D), S. carri, G. sanniolus new comb. and S. linearis by the laterally compressed body shape and and the nebulated pattern of broken up dorsal bands on a gray or brown background. It differs from $S$. anthracops (character states in parenthesis) by possessing 15 scale rows at midbody (vs. 13), possessing a nebulated dorsal color pattern (vs. tricolor banded pattern), incomplete banding on venter (vs. complete), and lacking a loreal that enters the orbit (vs. loreal entering orbit). It may be distinguished from $S$. dimidiatus by lacking a post-mental scale (usually one or two post-mental scales present), and possessing less than 80 subcaudals in males (vs. more than 95).
Distinct from the superficially similar Sibon nebulatus (Fig. 9A, B) by vertebral row of dorsal scales same size as other dorsal scales (vs. vertebral row of dorsal scales 1.25-1.35 times larger than other dorsal scales), smaller adult body size of $450-560 \mathrm{~mm}$ in males (vs. up to 890 $\mathrm{mm}$ in males), fewer dark body bands, 26-35 on body (vs. 36-47 on body), head predominately dark brown or black (vs. head pattern speckled with dark and light marking) and absence of pink speckling in the dorsal pattern (vs. pink speckling present).

It differs from Dipsas gaigeae by having 15 dorsal scale rows at midbody (vs. 13), possessing 179-189 ventral scales (vs. 155-169), loreal that does not enter orbit (vs. loreal enters orbit), and 26-35 pale body bands (vs. 7-12). Distinct from Dipsas brevifacies by possessing 179-189 ventral scakes (vs. 162-180), prefrontal and loreal not in contact with orbit (vs. variable in both), usually possessing $1+2$ temporals (vs. usually $2+3$ ), usually possessing one pair of infralabials in contact after the mental (vs. usually two pairs of infralabials in contact after the mental). Within Tropidodipsas, T. papavericola sp. nov. differs from $T$. fasciata and $T$. guerreroensis by possessing 15 smooth dorsal scale rows (vs. 17 keeled scale rows).

Tropidodipsas papavericola sp. nov. differs from $T$. tricolor sp. nov. by lacking the tricolor outline in the dorsal bands (vs. possessing a tricolor outline in dorsal bands), 26-35 dorsal dark bands on body (vs. 19-22), by possessing a prefrontal which does not enter orbit (vs. prefrontal entering orbit), 2 preoculars (vs. 1), 5-7 supralabials (vs. 7-8), 6-7 infralabials (vs. 8-9), less subcaudal scales, 6976 in males (vs. 78-79 in males), by possessing a pale ventral coloration of head with irregularly scattered dark spots, and a black and white mental (vs. pale ventral coloration of head with heavy dark stippling anteriorly and black mental), and by a smaller eye - head length ratio of 17-21\% (vs. $25 \%$ ). It is most similar to T. philippii (Fig. 8C, D), from which it can be distinguished by having smooth dorsal scales (vs. slightly keeled), a longer tail which is $30-35 \%$ of SVL in males (vs. 25-29\% in males), and less subcaudal scales, 69-76 in males (vs. 76-90 in males).

Genetic divergence in a 1,072-bp long fragment of the mitochondrial cytb gene between $T$. papavericola sp. nov. and T. philippii is $12-14 \%$; between T. papavericola sp. nov. and T. guerreroensis, 10-13\%; between T. papavericola sp. nov. and T. fasciata is $10-12 \%$.

Description of holotype. (Fig. 4) INIRENA 2801. Adult male. SVL $421 \mathrm{~mm}$; TL $137 \mathrm{~mm}$; TotL $558 \mathrm{~mm}$. HL $13.8 \mathrm{~mm}$ (from tip to posterior border of parietal) and $13.5 \mathrm{~mm}$ (from snout to posterior commissure of mouth); HW $9.8 \mathrm{~mm}$, head distinct from body, approximately 2 times wider than neck. Snout long, SL $5.7 \mathrm{~mm}$, contained 2.4 times in HL, rounded in dorsal and lateral profile. Loreal region tall, canthus rostralis angular. Rostral 1.2 times as broad as high $(3.3 \mathrm{~mm}$ wide, $2.7 \mathrm{~mm}$ high); internasals broader than long (1.7 mm length, 2.8 $\mathrm{mm}$ width), rounded anteriorly, in lateral contact with anterior and posterior nasals; prefrontals longer than broad, (3.8 mm length, $2.9 \mathrm{~mm}$ width), rectangular, in 
Table 3. Meristic variation of Tropidodipsas tricolor sp. nov. and Tropidodipsas papavericola sp. nov.

\begin{tabular}{|c|c|c|c|c|c|c|c|c|}
\hline \multirow{2}{*}{$\begin{array}{c}\text { Species } \\
\text { Specimen }\end{array}$} & \multicolumn{2}{|c|}{ T. tricolor sp. nov. } & \multicolumn{6}{|c|}{ T. papavericola sp. nov. } \\
\hline & INIRENA 2800 & INIRENA 2798 & INIRENA 2801 & INIRENA 2802 & INIRENA 2803 & INIRENA 2804 & INIRENA 2810 & INIRENA 2805 \\
\hline Sex & Male & Female & Male & Male & Male & Male & Male & Male \\
\hline Snout-vent Length & 210 & 310 & 421 & 366 & 363 & 430 & 258 & 336 \\
\hline Tail Length & 67 & 93 & 137 & 119 & 113 & 127 & 91 & 112 \\
\hline Total Length & 277 & 403 & 558 & 485 & 476 & 557 & 349 & 448 \\
\hline Head length & 8.30 & 13.62 & 18.97 & 15.25 & 15.83 & 18.58 & 13.03 & 14.92 \\
\hline Anterior Chinshield & $\begin{array}{l}\text { Longer than } \\
\text { wide }\end{array}$ & $\begin{array}{l}\text { Longer than } \\
\text { wide }\end{array}$ & $\begin{array}{l}\text { Longer than } \\
\text { wide }\end{array}$ & $\begin{array}{l}\text { Longer than } \\
\text { wide }\end{array}$ & $\begin{array}{l}\text { Longer than } \\
\text { wide }\end{array}$ & $\begin{array}{l}\text { Longer than } \\
\text { wide }\end{array}$ & $\begin{array}{l}\text { Longer than } \\
\text { wide }\end{array}$ & $\begin{array}{l}\text { Longer than } \\
\text { wide }\end{array}$ \\
\hline Posterior Chinshields & $\begin{array}{l}\text { Longer than } \\
\text { wide }\end{array}$ & $\begin{array}{l}\text { Longer than } \\
\text { wide }\end{array}$ & $\begin{array}{l}\text { Longer than } \\
\text { wide }\end{array}$ & $\begin{array}{l}\text { Longer than } \\
\text { wide }\end{array}$ & $\begin{array}{l}\text { Longer than } \\
\text { wide }\end{array}$ & $\begin{array}{l}\text { Longer than } \\
\text { wide }\end{array}$ & $\begin{array}{l}\text { Longer than } \\
\text { wide }\end{array}$ & $\begin{array}{l}\text { Longer than } \\
\text { wide }\end{array}$ \\
\hline Gulars & 3 & 3 & 4 & 4 & 5 & 4 & 5 & 5 \\
\hline $\begin{array}{l}\text { Infras in contact with } \\
\text { 1st CS }\end{array}$ & 5 & 5 & 5 & 4 & 4 & 5 & 4 & 4 \\
\hline Ventral Scales & 183 & 183 & 180 & 180 & 188 & 189 & 182 & 179 \\
\hline Subcaudal Scales & $79 / 79$ & $79 / 79$ & 76 & 74 left / 74 & $73 / 73$ & 69 & 74 & 73 \\
\hline Pre-oculars (Side) & 1.1 & $1.1^{\star}$ & 2.2 & 2.2 & 2.2 & 2.2 & 2.2 & 2.2 \\
\hline Post-oculars (Side) & 2.2 & 3.3 & 2.2 & 2.2 & 2.2 & 1.1 & 2.2 & 2.2 \\
\hline Anterior Temporals (Side) & 1.1 & 1.1 & 1.1 & 1.1 & 1.1 & 1.1 & 1.1 & 1.1 \\
\hline Posterior Temporals (Side) & 2.2 & 2.2 & 2.2 & 2.2 & 2.2 & 2.2 & 2.2 & 2.2 \\
\hline Supralabials (Side) & 8.7 & 7.8 & 7.7 & 6.6 & 6.7 & 5.6 & 7.7 & 6.6 \\
\hline Infralabials (Side) & 8.8 & 8.9 & 7.6 & 6.6 & 6.6 & 6.6 & 7.7 & 6.6 \\
\hline Post-mentals & 0 & 0 & 0 & 0 & 0 & 0 & 0 & 0 \\
\hline Pale Body Bands (Side) & 19.19 & 19.20 & - & 32.28 & 34.35 & 29.27 & 27.27 & 25.25 \\
\hline Pale Tail Bands (Side) & 9.9 & 8.8 & - & 14.12 & - & 11.11 & 15.16 & 13.13 \\
\hline Black Body Blotches (Side) & 19.19 & 19.21 & 32.33 & 30.31 & 35.35 & 27.27 & 29.28 & 26.26 \\
\hline Black Tail Blotches (Side) & 8.8 & 8.8 & 14.14 & 15.15 & - & 10.11 & 16.14 & 13.13 \\
\hline $\begin{array}{l}\text { Total Pale Body Blotch } \\
\text { Count (Body \& Tail) }\end{array}$ & 28.28 & 28.28 & 46.47 & 45.46 & 42.42 & 37.38 & 45.42 & 39.39 \\
\hline TL/TotL & 0.24 & 0.23 & 0.25 & 0.25 & 0.24 & 0.23 & 0.26 & 0.25 \\
\hline TL/SVL & 0.32 & 0.30 & 0.33 & 0.33 & 0.31 & 0.30 & 0.35 & 0.33 \\
\hline Internasal Length & 1.00 & 2.34 & 1.70 & 1.34 & 1.50 & 1.46 & 0.90 & 1.44 \\
\hline Internasal Width & 1.60 & 2.62 & 4.48 & 3.53 & 3.58 & 4.74 & 2.96 & 3.52 \\
\hline Loreal Length & $0.9 / 1.0$ & $1.19 / 1.10$ & $1.73 / 1.70$ & $1.46 / 1.38$ & $1.36 / 1.34$ & $1.26 / 1.22$ & $1.0 / 1.0$ & $1.40 / 1.38$ \\
\hline Loreal Width & $1.0 / 1.0$ & $1.24 / 1.12$ & $1.84 / 1.82$ & $1.45 / 1.2$ & $1.38 / 1.42$ & $1.40 / 1.46$ & $0.92 / 0.94$ & $1.30 / 1.26$ \\
\hline Loreal into orbit & No & No & No & No & No & No & No & No \\
\hline Pre-frontal Length & 1.70 & 2.34 & 3.39 & 2.81 & 2.89 & 3.26 & 2.48 & 2.36 \\
\hline Pre-frontal Width & 2.00 & 2.64 & 5.75 & 4.69 & 4.69 & 5.06 & 3.84 & 4.33 \\
\hline Prefrontal into orbit & Yes & Yes & No & No & No & No & No & No \\
\hline Frontal Length & 2.80 & 2.88 & 4.23 & 3.58 & 3.71 & 3.93 & 3.31 & 3.60 \\
\hline Frontal Width & 2.40 & 2.70 & 3.81 & 2.73 & 3.35 & 3.35 & 2.71 & 3.08 \\
\hline Parietal Length & 4.30 & 5.54 & 6.58 & 6.82 & 5.51 & 6.26 & 4.61 & 5.28 \\
\hline $\begin{array}{l}\text { Length Anterior Chin- } \\
\text { shields }\end{array}$ & $2.4 / 2.6$ & $3.49 / 3.63$ & 4.73 & 4.03 & 4.31 & 5.72 & 3.33 & 3.58 \\
\hline $\begin{array}{l}\text { Length Posterior Chin- } \\
\text { shields }\end{array}$ & $1.9 / 1.8$ & $2.28 / 2.42$ & 3.72 & 1.94 & 2.25 & 2.67 & 1.81 & 2.15 \\
\hline Eye Diameter & 2.10 & 2.80 & 3.20 & 3.02 & 3.11 & 3.56 & 2.71 & 2.85 \\
\hline $\mathrm{ED} / \mathrm{HL}$ & 0.25 & 0.21 & 0.17 & 0.20 & 0.20 & 0.19 & 0.21 & 0.19 \\
\hline Pre-Frontal Length/Width & 0.85 & 0.89 & 0.59 & 0.60 & 0.62 & 0.64 & 0.65 & 0.55 \\
\hline $\mathrm{HL} / \mathrm{SVL}$ & 0.04 & 0.04 & 0.05 & 0.04 & 0.04 & 0.04 & 0.05 & 0.04 \\
\hline Midbody scale rows & 15 & 15 & 15 & 15 & 15 & 15 & 15 & 15 \\
\hline Head scale rows & 15 & 15 & 15 & 15 & 15 & 15 & 15 & 15 \\
\hline Caudal scale rows & 15 & 15 & 15 & 15 & 15 & 15 & 15 & 15 \\
\hline Lateral compresion & Yes - Extreme & $\begin{array}{l}\text { Yes - Ex- } \\
\text { treme }\end{array}$ & Yes - Oval & Yes - Oval & Yes - Oval & Yes - Oval & Yes - Oval & Yes - Oval \\
\hline Anal plate & Undivided & Undivided & Undivided & Undivided & Undivided & Undivided & Undivided & Undivided \\
\hline $\begin{array}{l}\text { Penultimate supralabial } \\
\text { enlarged }\end{array}$ & Yes & Yes & Yes & Yes & Yes & Fused & Yes & Yes \\
\hline First infraliabals in contact & Yes & Yes & Yes & Yes & Yes & Yes & Yes & Yes \\
\hline Pale nuchal band & Yes & Yes & Yes & Yes & Yes & Yes & Yes & Yes \\
\hline
\end{tabular}

median contact with each other and in lateral contact with postnasal, loreal, upper preocular and supraocular; frontal 1.1 times longer than broad, (4.4 mm long, 3.9 $\mathrm{mm}$ broad), pentagonal with angular tip posteriorly, in contact with prefrontals, supraoculars and parietals. Two moderately large preoculars on each side, upper larger than lower. Single supraocular large, in contact with upper preocular, prefrontal, frontal, parietal, and upper postocular. Two moderately large postoculars on each side, upper one larger than lower. Parietal 1.4 times as long as wide (6.0 $\mathrm{mm}$ long, $4.2 \mathrm{~mm}$ wide), the length of parietal $61 \%$ of HL, the common suture between parietals $4.4 \mathrm{~mm}$, equal to frontal length. Nasal divided, prenasal slightly taller than postnasal, with combined 


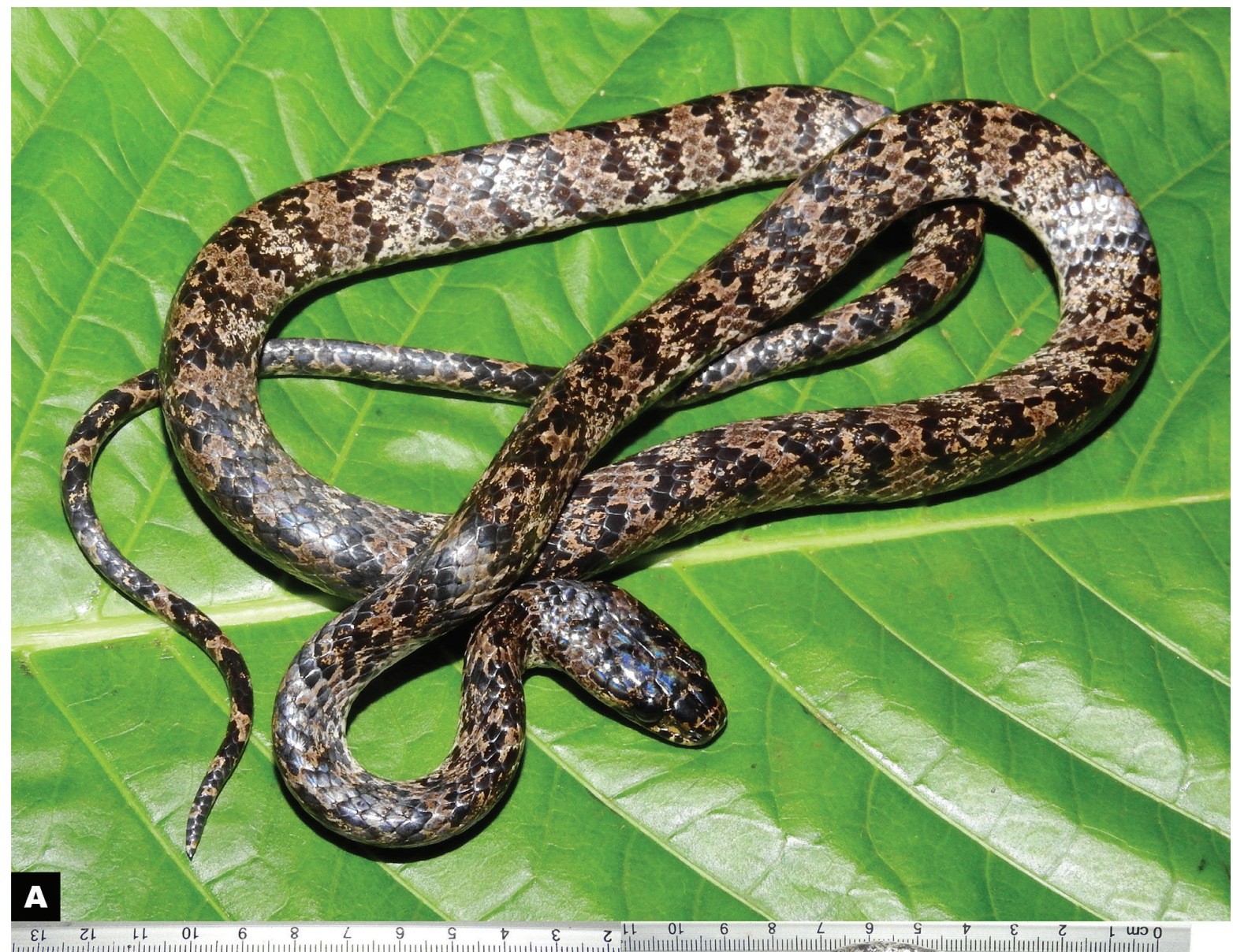

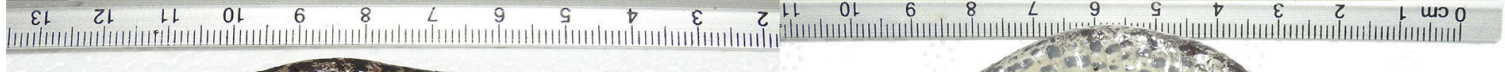
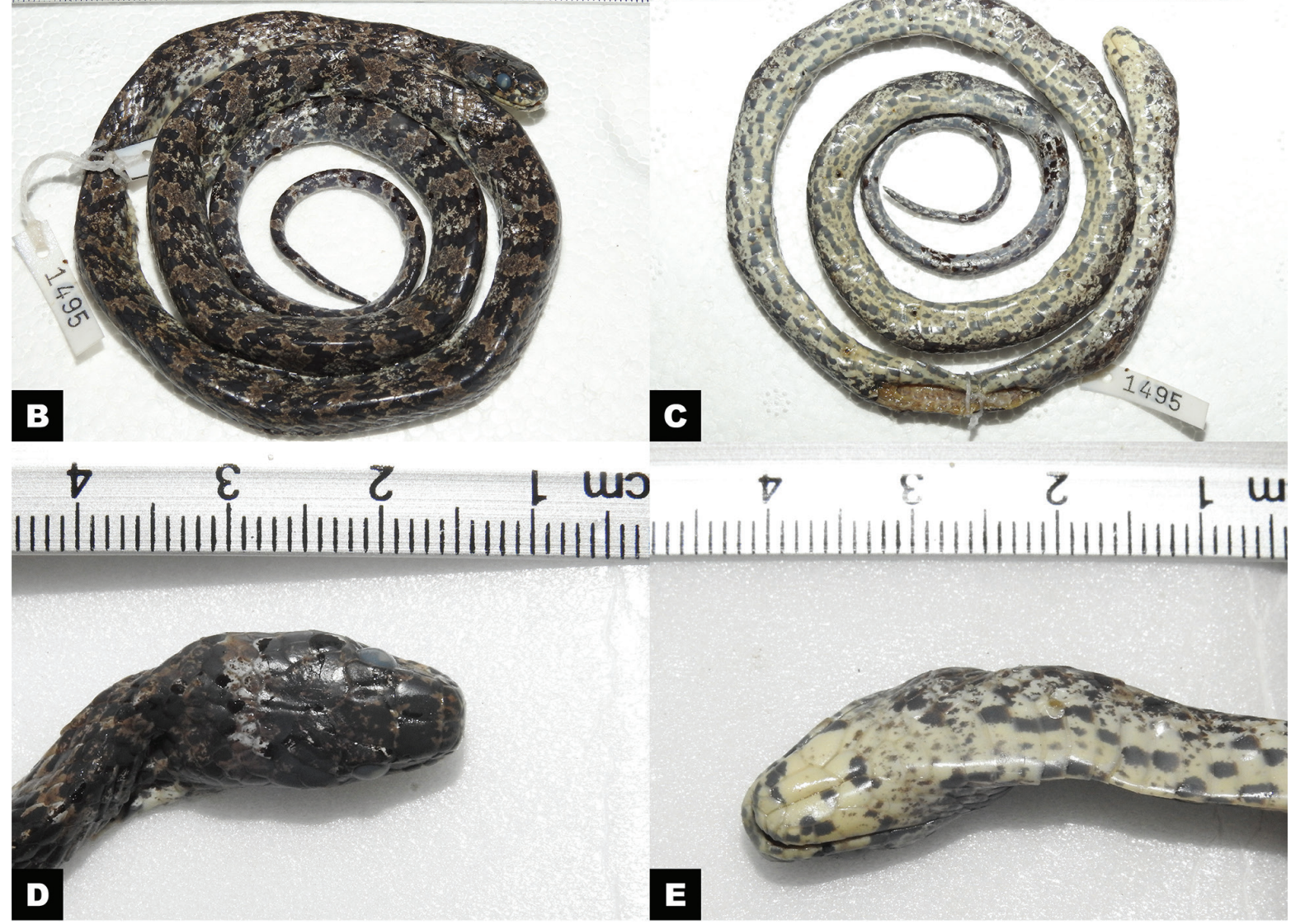

Figure 4. Tropidodipsas papavericola sp. nov. Holotype (INIRENA 2801). Holotype (INIRENA 2801) in life (A); Ventral aspect of Holotype (INIRENA 2801) in preservative (B,E); Dorsal aspect of Holotype (INIRENA 2801) in preservative. 


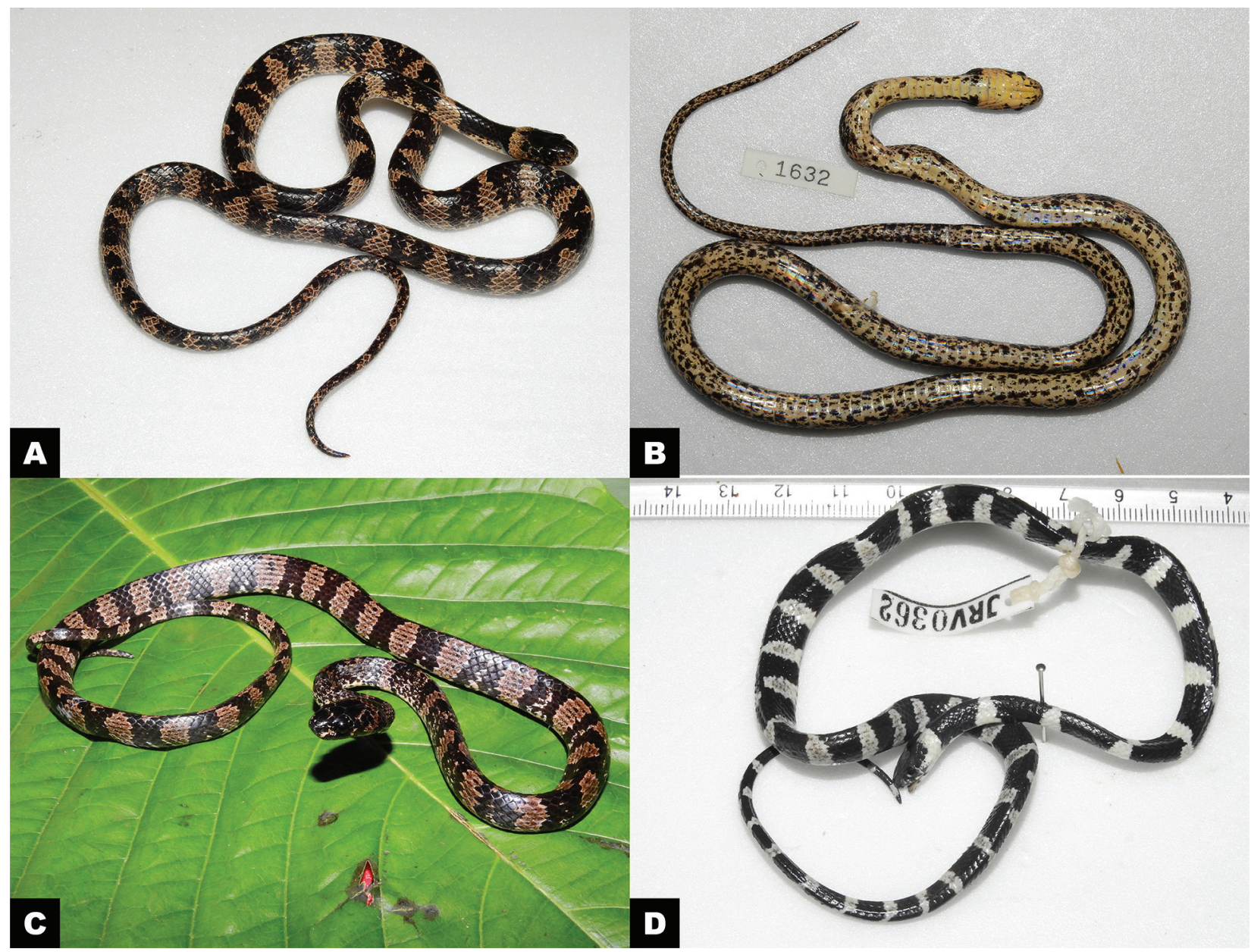

Figure 5. Tropidodipsas papavericola sp. nov. Variation. Male (INIRENA 2804) from Municipio de Técpan de Galeana, Guerrero (A-B); Male (INIRENA 2802) from Municipio de Leonardo Bravo, Guerrero (B); Juvenile male (INIRENA 2810) from Municipio de Técpan de Galeana, Guerrero (D).

length of both nasals $2.6 \mathrm{~mm}$, longer than loreal. Loreal small, slightly longer than high and almost square, 1.4 high, $1.7 \mathrm{~mm}$ long on left side, $1.6 \mathrm{~mm}$ high, $1.8 \mathrm{~mm}$ long on right side, not reaching orbit. Eye moderately large, $3.1 \mathrm{~mm}, 23 \%$ of HL. Supralabials 7 on both sides, first in contact with nasals, second and third in contact with loreal, fourth and fifth entering orbit, sixth largest and in contact with lower postocular, anterior and posterior temporals. Temporals $1+2$. Five nuchal scales in contact with parietals.

Mental 2.4 times as broad as long (2.6 mm broad, 1.1 $\mathrm{mm}$ long), flat anteriorly, triangular posteriorly and separated from the anterior chinshields by the first pair of enlarged infralabials which are in contact with each other. Infralabials $7 / 8$; on the left $1-5$ in contact with anterior chinshields and fifth in contact with posterior chinshield; on the right 1-6 in contact with anterior chinshields and sixth in contact with posterior chinshield. Anterior chinshields irregular, both 2.3 times as long as wide (left 4.6 $\mathrm{mm}$ long and $2.0 \mathrm{~mm}$ wide, right $4.4 \mathrm{~mm}$ long and 1.9 $\mathrm{mm}$ wide). Left posterior chinshield 1.6 times as long as wide ( $3.5 \mathrm{~mm}$ long, $2.0 \mathrm{~mm}$ wide), and right posterior chinshield 1.3 times as long as wide (2.6 mm long, 2.0 mm wide). Four gular scales. Infralabials and scales in the chin region smooth. Dorsal scales in 15-15-15 rows, smooth throughout body; apical pits not evident. Ventrals 180; anal plate single; 76 paired subcaudal scales. Body laterally compressed. Pupil elliptical.

Coloration in life of the holotype (Fig. 4A). Dorsal coloration of head, body and tail brown with 32/33 irregular dark brown bands on the body and neck which all have pale centers that are stippled with paler brown and pale cream. Pale brown nuchal band two body scale rows long but reduced to one at the mid-dorsal line; not involving the posterior part of the parietals. Dark bands on body and tail 3-7 scale rows long, widest mid-dorsally, and alternating on posterior half of body. Head coloration predominately dark brown on dorsal surface and with light brown mottling and pale cream on rostral and anterior labials. First three supralabials bicolor pale cream and dark brown, posterior two supralabials bicolor dark brown with pale brown. Ventral coloration of head pale cream with irregular dark brown blotches. Ventral coloration of body pale yellowish cream, with dark and pale bands incomplete on venter. The ventral pattern consists of longitudinal rows of dark spots that connect to 
form irregular longitudinal lines. Anal plate bicolor, dark brown and pale cream. All 15 dark bands on tail incomplete ventrally, dark coloration forming longitudinal lines ventrally on tail. Tail tip pale cream with black tip. Pupil black, iris dark chocolate-gray.

Coloration in preservative of the holotype (Figs 4BE). General coloration bicolor. Dorsal surfaces of head, body and tail predominately dark brown with darker brownblack bands. Pale bands brown-gray, but whitish in a few places where stratum corneum has been removed (snake was going into shed when preserved). The dark bands remain brown-black and the pale cream faded to white.

Variation. Meristic variation of five available specimens given in Table 3. Variation in color and pattern detailed below (Fig. 5).

Color in life. A sub-adult male paratype from above Nueva Dehli, Municipio de Atoyac de Álvarez, Guerrero (INIRENA 2802) had a pale brown body coloration with $31 / 29$ dark brown bands on body and neck posterior to pale nuchal band and 14 on the tail. This specimen has light centers in all dark body bands, albeit limited to the lateral portions only. This implies that the irregular dark banding with light centers may be subject to ontogenetic variation, as this specimen is intermediate in size and pattern between the juvenile INIRENA 2810 and the large adult holotype INIRENA 2801. Neither the pale body bands, nor the dark body bands, are complete ventrally, reaching only to the lateral edges of the ventrals. The venter was cream or pale tan mid-ventrally with two dark brown irregular longitudinal stripes running down the length of the entire venter. The lines run into the remnants of the dark brown dorsal bands on the edges of the venter (Fig. 5C).

Color in preservative. An adult male paratype from above Bajitos de la Laguna, Municipio de Técpan de Galeana, Guerrero (INIRENA 2804) has 29/27 dark bands on the body posterior to the pale nape band and 12 on the tail. This specimen differs from the holotype because it has a relatively well-defined pattern of dark and pale bands with regular edges. Furthermore, the first well-defined dark band on the neck does not have a pale center, and on the second dark body band the pale center is interrupted mid-dorsally. The venter is white and covered with irregular black spots that do not form longitudinal rows of spots nor are fused into lines and dashes (Fig. 5A, B).

A juvenile male paratype from above San Luis La Loma, Municipio de Técpan de Galeana, Guerrero (INIRENA 2810) has 28/29 dark bands on the body and neck posterior to the pale nuchal band and 16 on the tail. This specimen lacks any light centers in the dark body bands of the tail, suggesting that this color pattern may be subject to an ontogenetic shift from juveniles to adults. It has black stippling in the light interspaces reminiscent of T. tricolor sp. nov. Both the pale body bands and the dark body bands are not complete ventrally, reaching only onto the lateral edges of the ventrals. The venter (in preservative) is white mid-ventrally, with two irregular longitudinal stripes running down the length of the entire venter. The lines run into the remnants of the dark dorsal bands on the edges of the venter (Fig. 5D).

An adult male paratype from above San Luis La Loma, Municipio de Técpan de Galeana, Guerrero (INIRENA 2803) has 35 dark bands on body and neck posterior to the pale nuchal band. None of the dark bands have pale centers mid-dorsally, some have the pale centers on the lateral portions of the body and others lack them altogether. Ventral coloration white with black blotches forming an irregular "checkerboard" pattern. No pale or dark body bands complete on venter.

A sub-adult male paratype, from above Técpan de Galeana, Guerrero (INIRENA 2805) has 26 dark bands on body and neck posterior to the pale nuchal band, all with faded pale centers in the dark body bands, most of them extensive but incomplete mid-dorsally. It has 12 dark bands on the tail and a dark tail tip. Ventral coloration white with dark gray mottling, with no dark or pale dorsal bands complete on venter, but the dense mottling makes the dark dorsal bands on posterior portion of body connect in an alternating undulated pattern.

Dentition. The holotype (INIRENA 2801) appears to have 14 maxillary teeth visible, however we did not remove the maxillary arch to avoid damaging the specimen.

We observed in situ the maxillary arch and dentition of the holotype (INIRENA 2801): it has 14 maxillary teeth and 20-22 dentary teeth.

An adult male paratype (INIRENA 2805) has 17 maxillary teeth (counting empty sockets) on the right side. We counted 22 dentary teeth on the right dentary of this same specimen.

Distribution, habitat and ecology. This species appears to be restricted to moderate elevations in the Sierra Madre del Sur in central Guerrero in two distinct areas (Fig. 10). Habitats include cloud forest, mesic pine-oak woodland, tropical evergreen forest, tropical semi-deciduous forest and combinations of these assemblages. Known from around 1600-2200 m a.s.1. in the Sierra de Técpan de Galeana, Sierra de Atoyac and above Acapulco, in the foothills in the area encompassed between Acahuizotla and El Treinta. Specimens were found at night during the rainy season on low to medium $(1.5-3.0 \mathrm{~m})$ vegetation or crossing the road.

Etymology. The specific epithet papaver + cola refers to the living among poppy plants (genus Papaver) which are illegally planted throughout the range of this species for the extraction of opium gum.

\section{Discussion}

\section{Generic identity of Tropidodipsas annulifera, T. sartorii and Sibon sanniolus}

Our molecular analyses confirm the results of Sheehy (2013) that some species previously included in Tropi- 

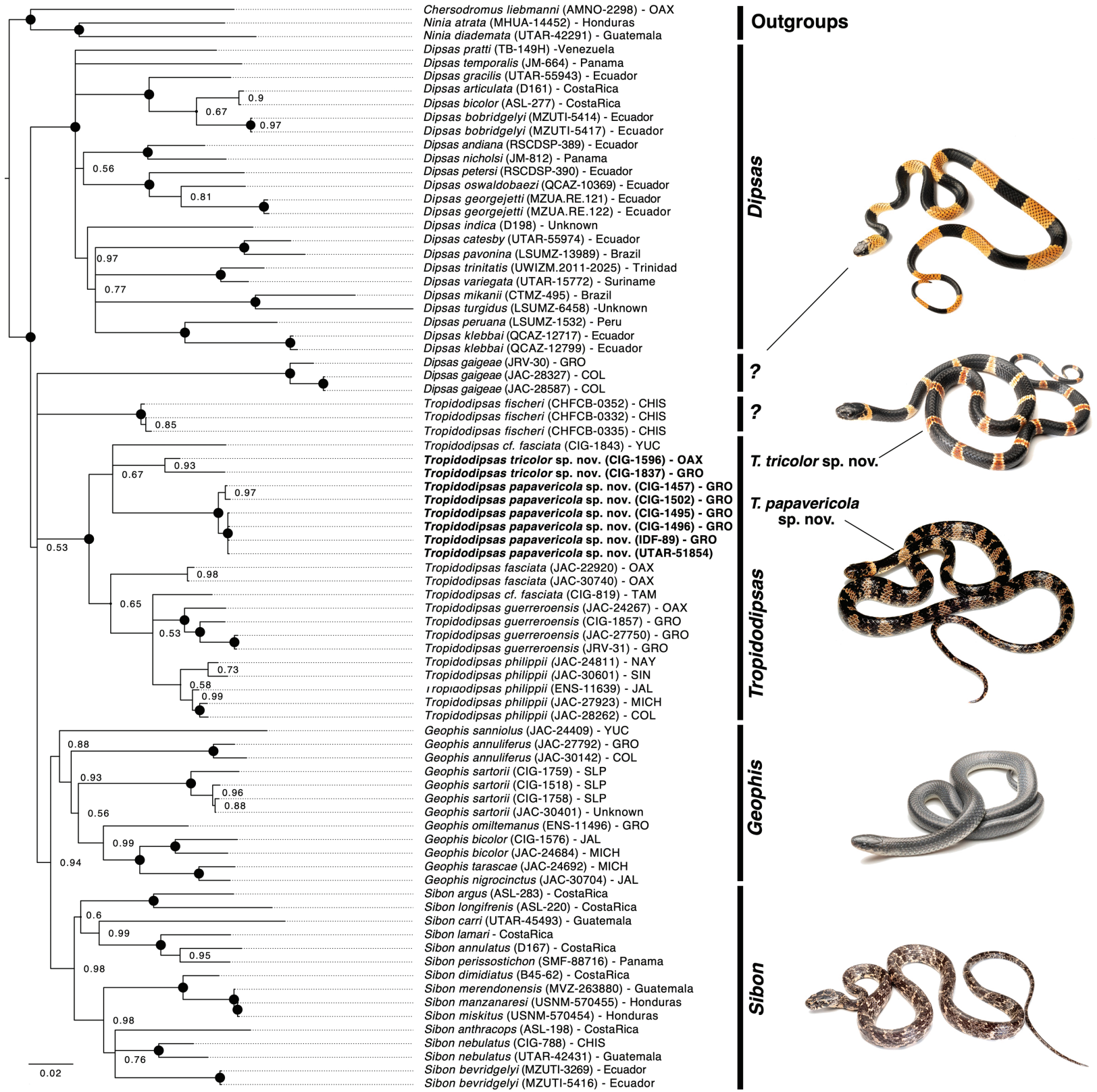

Figure 6. Bayesian phylogenetic inference of members of the Dipsadidae based on two mitochondrial loci and two nuclear loci. All nodes with support of less than 0.5 are collapsed, while those with posterior support equal to 1 are marked with a black dot. New species described here in bold.

dodipsas and Sibon (T. annulifera, T. sartorii and S. sanniolus) are actually more closely related to members of the genus Geophis than to other snail-suckers. However, we disagree with Sheehy's (2013) recommendation that new genera should be erected for each of these species. Instead, we consider it more appropriate for taxonomic stability to regard these three species as members of the genus Geophis, with the following new combinations: Tropidodipsas annulifera Boulenger $1894=$ Geophis annuliferus comb. nov. (Boulenger, 1894); Tropidodipsas sartorii Cope 1863 = Geophis sartorii comb. nov. (Cope 1863); and Sibon sanniolus (Cope 1866) = Geophis sanniolus comb. nov. (Cope 1866). We refrain from assign- ing the two species of the Tropidodipsas sartorii species group (sensu Kofron 1988; Smith et al. 2005) for which we do not have genetic material (T. repleta and T. zweifeli) to Geophis, and provisionally retain them in Tropidodipsas, although it has been suggested by previous authors that a close phylogenetic relationship between these taxa is likely (e.g., Kofron 1988). It should be noted that synonyms of both $G$. annuliferus comb. nov. and G. sartorii comb. nov. have previously been described in the genus Geophis. Geophis tecpanecus Dugès 1896 was synonymized with G. annuliferus comb. nov. by Scott (1967) and Geophis annulatus Peters 1870 was synonymized with G. sartorii comb. nov. by Boulenger (1894). 


\section{Content of the genus Tropidodipsas}

As revised here, the genus Tropidodipsas thus comprises eight species: Tropidodipsas fasciata Günther 1858, T. fischeri (Boulenger, 1894), T. guerreroensis Taylor, 1939 (see comment below), T. papavericola sp. nov., T. philippii (Jan, 1863), T. repleta Smith, Lemos-Espinal, Hartman \& Chiszar, 2005, T. tricolor sp. nov. and T. zweifeli Liner \& Wilson, 1970. The two species described herein are each other's closest relative and comprise a clade together with samples assigned to $T$. fasciata from the Yucatán Peninsula (Fig. 7B). These two species together with T. philippi, T. guerreroensis, and the various populations assigned to T. fasciata form a species group that we continue to recognize as the T. fasciata species group (Kofron 1987, Wallach 1995). The phylogenetic relationships of Tropidodipsas repleta and T. zweifeli are unknown as no genetic data currently exist for these species. With the removal of Geophis annuliferus new comb. and G. sartorii new comb. these two species become unassignable to a species group. Genetic material of these two species is needed to determine whether their relationship is indeed with Tropidodipsas, or whether they should also be placed in Geophis. The generic affinities of Dipsas gaigae (Oliver, 1937) and Tropidodipsas fischeri (Boulenger, 1894) are not clear as they render their respective genera paraphyletic, and these two species probably deserve their own monotypic genera as suggested by previous authors (Kofron 1985b; Fernandes 1995; Sheehy 2013). However, this is beyond the scope of this paper and we provisionally retain them in their respective genera.

\section{Identity of Tropidodipsas guerreroensis Taylor, 1939}

Tropidodipsas guerreroensis was described by Taylor (1939) as a member of the genus Tropidodipsas that he considered closely related to T. fasciata. Later, Álvarez del Toro and Smith (1956) relegated it to a subspecies of T. fasciata, an arrangement followed by Kofron (1980, 1987). Mertz et al. (2010) reported a specimen (UTADC $3701=$ JRV-31) purportedly of this form from western Guerrero as a range extension of T. fasciata (Fig. 7C), as that journal did not accept the use of subspecies at the time. Sheehy (2013) included this specimen in his study, along with a second specimen (JAC 27750) from the vicinity of Hwy.134 in western Guerrero. He mistakenly referred to this specimen as T. philippii. In his phylogenetic analysis he also included a third specimen from the vicinity of Candelaria Loxicha, Oaxaca (JAC 24267), which he labeled as a potential undescribed species.

We included all three of these specimens in our analyses, along with a specimen from central Guerrero (INIRENA 2781) collected relatively near the type locality of T. guerreroensis $(<90 \mathrm{~km})$ that fits the original descrip- tion very well (Fig. 7D). Our samples encompass the currently known distribution of the species, ranging from western Guerrero east to near Candelaria Loxicha in the south-central portion of the Sierra Madre del Sur of Oaxaca. The genetic distances of the mitochondrial gene $c y t b$ between the westernmost specimens of $T$. guerreroensis on Hwy. 134 in Guerrero and the easternmost specimen from near Candelaria Loxicha in Oaxaca is less than 6\%, suggesting that all four specimens belong to one cohesive lineage, albeit with considerable intraspecific divergence, probably the result of isolation-by-distance.

In contrast, the easternmost individual of $T$. guerreroensis (Candelaria Loxicha, Oaxaca) has a genetic distance of $12.4-12.5 \%$ compared to nearby $T$. fasciata from various localities in the Isthmus of Tehuantepec, Oaxaca (Fig. 8A, B). For comparison, the western population of T. guerreroensis (Hwy. 134, Guerrero) has a genetic distance of $6.9-8.5 \%$ from the nearest sampled T. philippii in Michoacán, which suggests a closer relationship to $T$. philippii than to T. fasciata, as shown by our phylogenetic analyses, or recent gene flow. Thus, we suggest that $T$. guerreroensis represents a diagnosable, monophyletic species that is closest related to T. philippii.

These results show that among Mexican snail-suckers inter-population intra-specific genetic distances of the $c y t b$ mitochondrial gene range from 3-7\%, whereas inter-specific genetic distances of closely related species (such as T. philippii, T. guerreroensis, and T. fasciata) range between $7-10 \%$ and other species have genetic distances $>10 \%$. It is notable that in our results intraspecific distances of cytb are less than $0.7 \%$ in T. papavericola sp. nov., less than $0.4 \%$ in $T$. fasciata, but $3-6 \%$ in $T$. guerreroensis.

\section{Unassigned museum specimens from southern Oaxaca}

Kofron (1980) described a specimen (LACM 104321) from the Sierra Madre del Sur of Oaxaca as "Sibon sp. cf. philippii". He apparently considered the specimen to be of enough significance that he provided a detailed description, including scalation and color pattern, and even gave comparisons of how it differed from other Tropidodipsas philippii. He also recognized the uniqueness of the habitat compared to that of other T. philippii, but he refrained from designating a name for this form. Later, Kofron (1987) included this specimen, along with three others from Oaxaca (KU 137655, UCM 49372, UIMNH 73681) in his "Sibon philippii" (=Tropidodipsas philippii). He did not give any further explanation as to why he placed these specimens in T. philippii, and the scale counts and ranges given by him for T. philippii include these specimens.

It is important to note that these southern specimens are over $750 \mathrm{~km}$ from the nearest populations of T. philippii in Michoacán, and originate from elevations between 


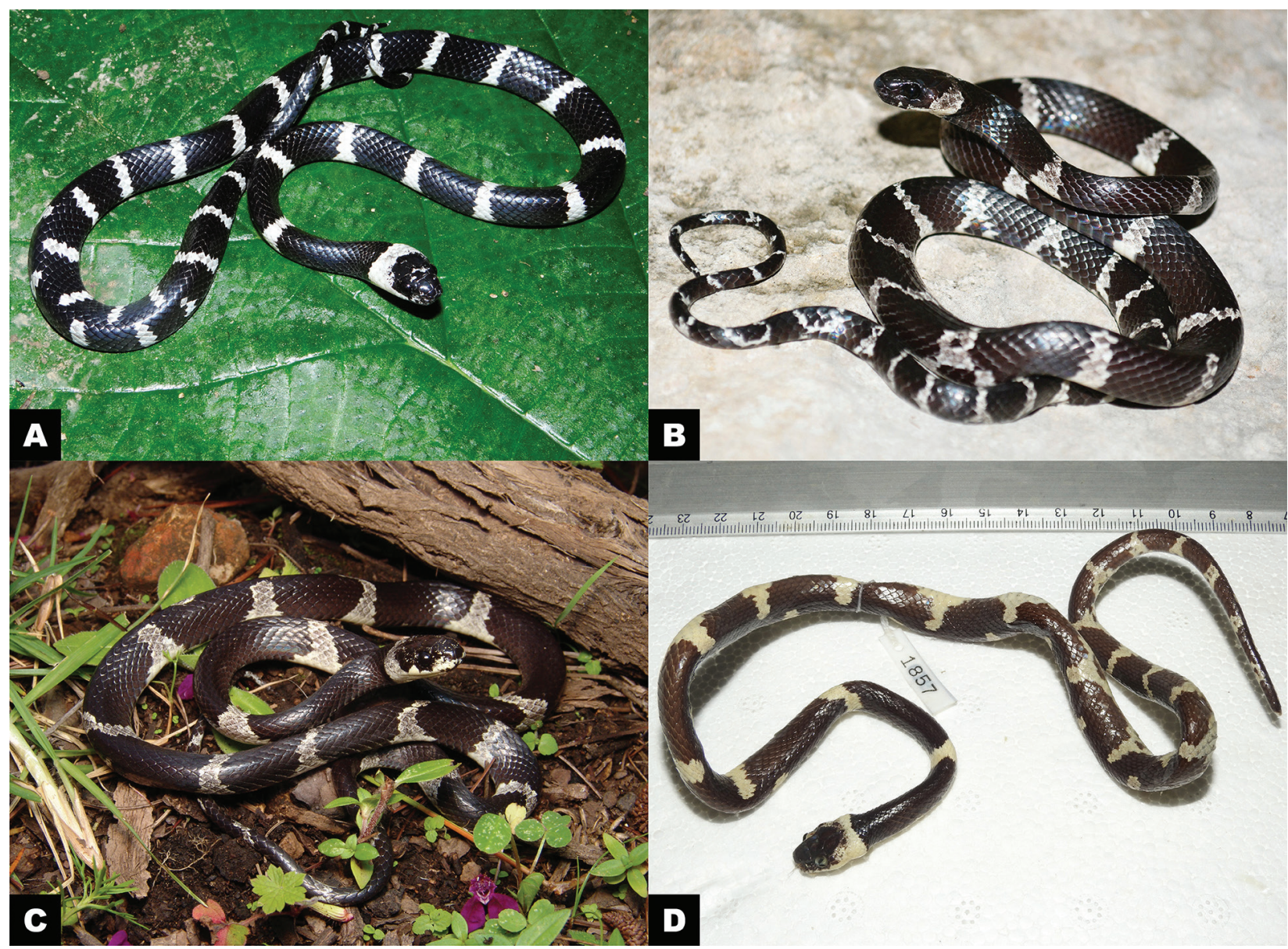

Figure 7. Closely related species of Tropidodipsas from southern Mexico. Tropidodipsas cf. fasciata from Municipio de Ocampo, Tamaulipas (A); Tropidodipsas cf. fasciata from Municipio de Merida, Yucatan (B); Tropidodipsas guerreroensis from Municipio de José Azueta, Guerrero (C); Tropidodipsas guerreroensis from Municipio de Atoyac de Álvarez, Guerrero (D).

1600-2100 m a.s.1., whereas T. philippii is known from elevations usually below $1500 \mathrm{~m}$ a.s.l. We have reviewed detailed photographs of three of these specimens (LACM 104321, KU 13766, UCM 49372) and it is likely that these high-elevation populations are referable to T. $p a$ pavericola sp. nov. or represent an undescribed species, closely related to it. We were not able to examine the other specimen (UIMNH 73681) from southern Oaxaca due to institution closures related to the Covid-19 pandemic. Unfortunately, genetic material is not available for the high-elevation populations of Tropidodipsas from the Sierra Madre del Sur of Oaxaca. Future collecting is necessary to properly assign these populations to a species.

\section{The occurrence of Geophis sartorii new comb. along the west coast of Mexico}

Sheehy (2013) included a specimen of Geophis sartorii new comb. (JAC 30401) purportedly from the vicinity of El Tuito, Jalisco, in his phylogenetic analyses. Geophis sartorii new comb. is restricted to eastern Mexico, so a specimen of this species from Jalisco greatly increased the known range of the species. The sample did indeed group with G. sartorii new comb. in Sheehy's genetic analysis and not with the superficially similar G. annuliferus comb. nov., which is known from that region of Jalisco. We inquired about this specimen at the UTA collection and were informed that it was collected by $\mathrm{Mr}$. Paulino Ponce-Campos. We contacted Mr. Ponce-Campos about the provenance of this specimen, and he told us that he specifically remembers providing the UTA field crew with a specimen of $G$. sartorii new comb. that he had collected in the state of San Luis Potosí and given them while they were in Jalisco.

Considering that Sheehy (2013) does not list any Geophis sartorii new comb. as coming from San Luis Potosí, we suggest it is very likely that this is the correct provenance of JAC 30401 and the locality listed by Sheehy (2013) was confused with another specimen with origins in Jalisco. This is further supported by the fact that the genetic distances of a fragment of the mitochondrial gene $c y t b$ between JAC 30401 and two G. sartorii new comb. (INIRENA 12783-84) which we collected in San Luis Potosí is 0.0. We have included this specimen (JAC 30401) as "locality unknown" and strongly doubt that G. sartorii new comb. is present in the state of Jalisco. However, Geophis sartorii macdougalli new comb. was 


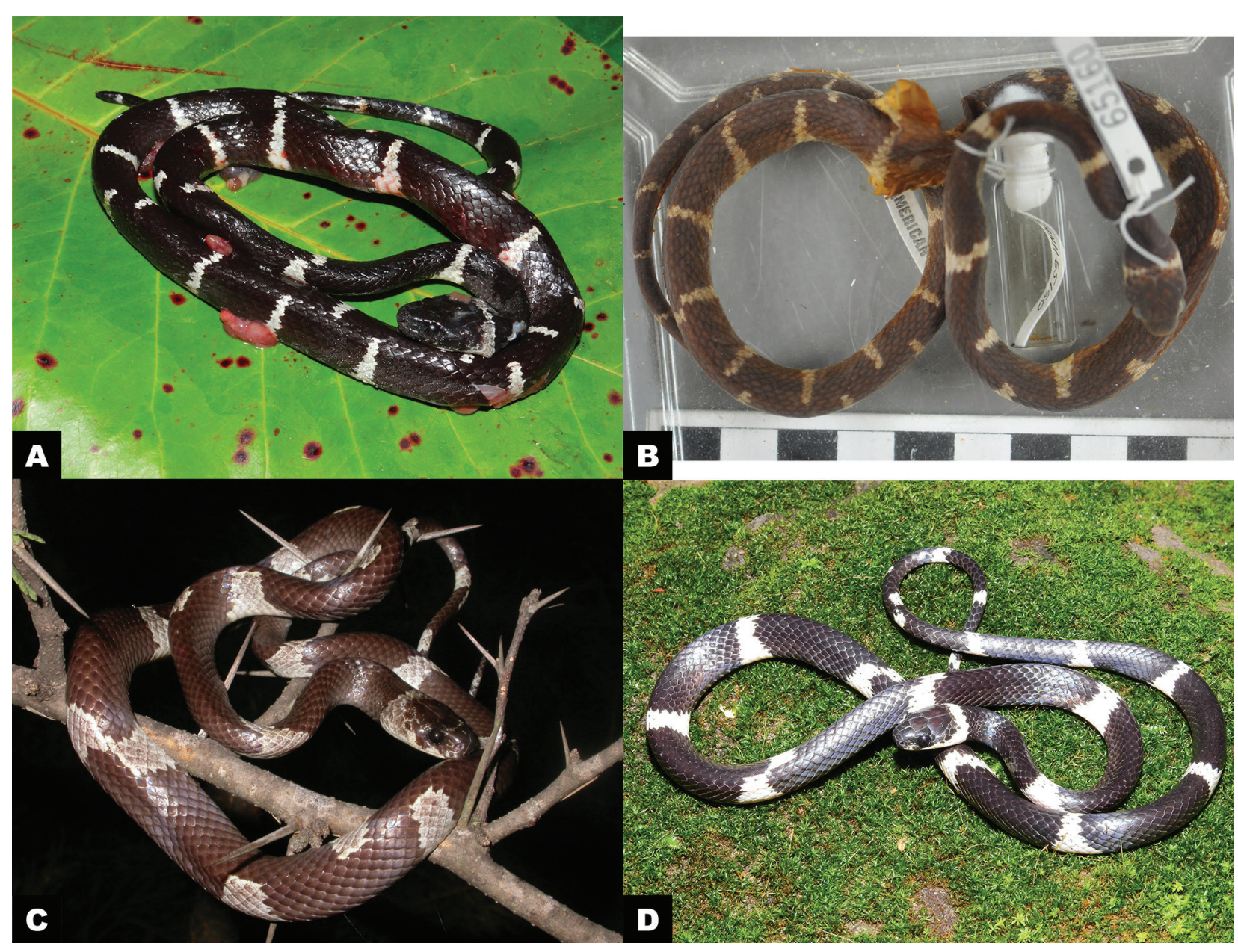

Figure 8. Closely related species of Tropidodipsas from southern Mexico. Tropidodipsas fasciata from Municipio de Santo Domingo Zanatepec, Oaxaca (A-B); Tropidodipsas philippii from Municipio de Minatitlán, Colima (C-D).

recently reported from the Pacific versant of Guerrero by Blancas-Hernández et al. (2019). It would be interesting to verify the identity of this Guerreran population with molecular tools and assess how it is related to populations of G. sartorii new comb. on the Atlantic versant of Mexico and around the Isthmus of Tehuantepec. If the Guerrero population indeed belongs to G. sartorii new comb., then the presence of additional populations of $G$. sartorii new comb. on the Pacific versant of Mexico can be expected.

\section{Conservation priorities for the new Tropidodipsas}

The species of Tropidodipsas described above are the two species with the smallest known range in the genus, and likely are also the two species needing the most conservation attention. Tropidodipsas papavericola $\mathrm{sp}$. nov. can be considered micro-endemic. It is known from only one biogeographical formation (\#48 - Guerreran Sierra Madre del Sur Mixed Temperate Woodland) as defined by Grünwald et al. (2015). While it is currently known from four distinct localities, all fall within this biogeographical formation or right at its lowermost limit.
Widespread illegal logging is present at two of the localities (pers. obs.) and illicit poppy farming is present at or near all four localities. As poppy prices drop due to international supply and demand, and competition from synthetic drugs such as fentanyl, illicit poppy farmers tend to fluctuate to other businesses. This often leads to illegal logging (pers. obs.) and thus widespread habitat destruction. We suggest that this new species be awarded the highest conservation category possible by the Mexican government, and that studies are undertaken to determine its vulnerability to the habitat destruction caused by illegal logging. Also, further sampling should focus on southern Oaxaca to determine whether populations from the Sierra Madre del Sur above San Gabriel Mixtepéc are assignable to this species.

Tropidodipsas tricolor sp. nov. is apparently widely distributed along the windward slopes of the Sierra Madre del Sur of Guerrero and Oaxaca. It has been collected in three biogeographical formations (\#12 - Guerreran Tropical Dry Forest \& Savanna; \#48 - Guerreran Sierra Madre del Sur Mixed Temperate Woodland; \#49 - Malinaltepec - Putla Sierra Madre del Sur Mixed Temperate Woodland) as defined by Grünwald et al. (2015). The type locality experiences small-time agricultural disturbance and some logging, 

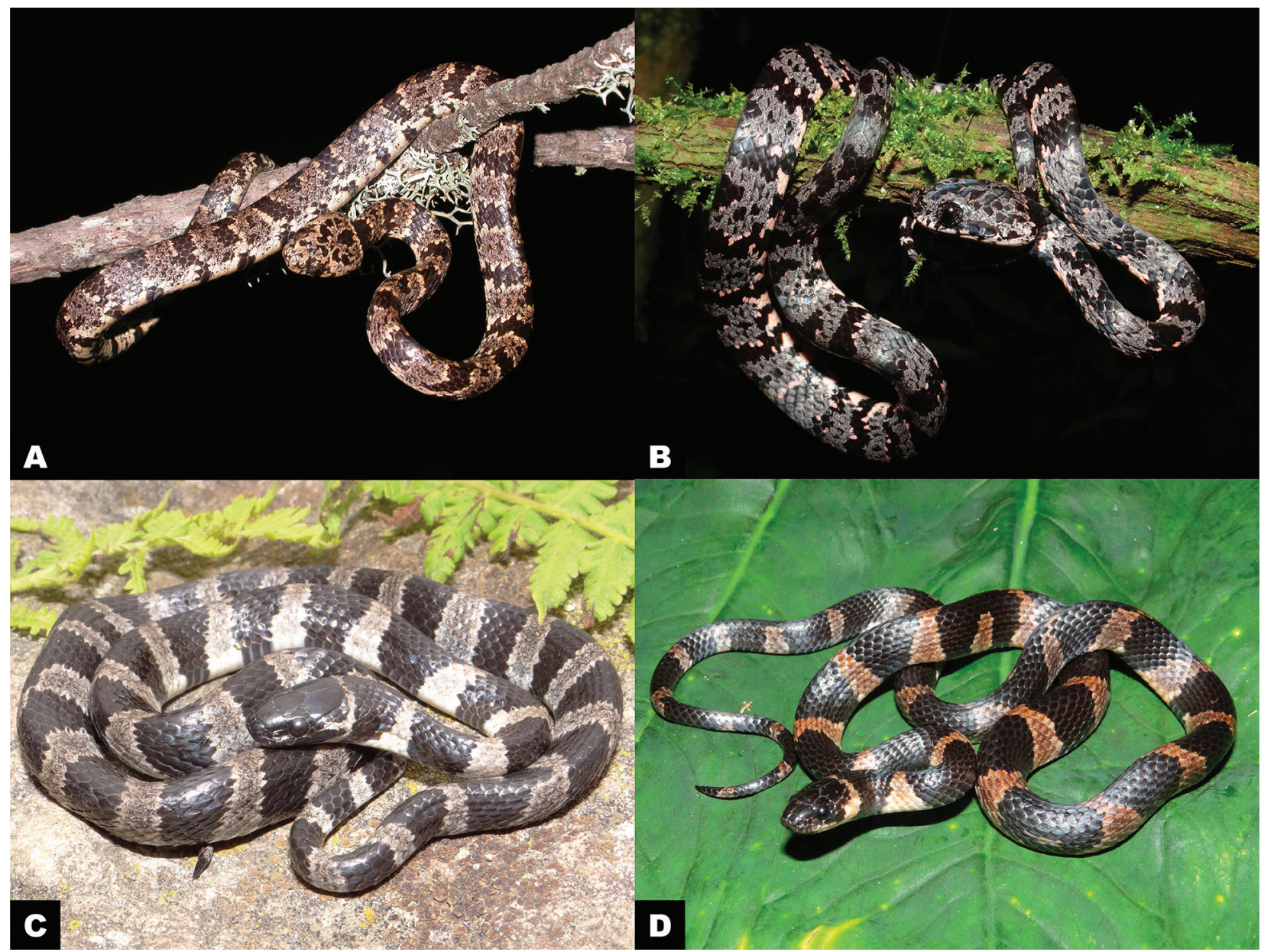

Figure 9. Similar looking but not closely related snail-suckers from southern Mexico. Sibon nebulatus from Municipio de Ixtlahuacán, Colima (A); Sibon nebulatus from Municipio de Las Margaritas, Chiapas (B); Tropidodipsas fischeri from Municipio de Rayón, Chiapas (C); Tropidodipsas fischeri from Municipio de Unión Juárez, Chiapas (D).

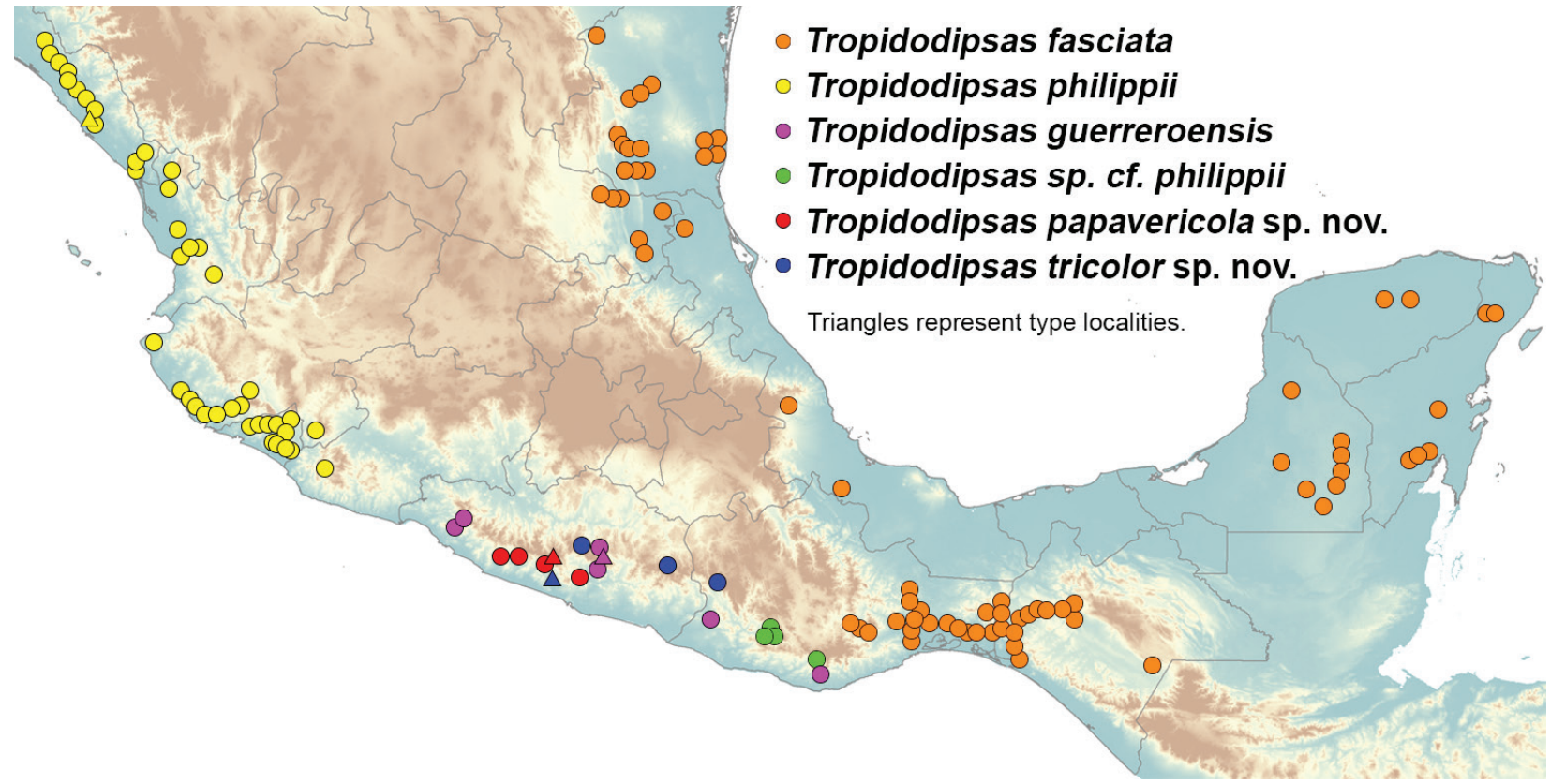

Figure 10. Distribution map of species in the Tropidodipsas fasciata species group in Mexico. Triangles represent type localities, type localities are only mapped when known with certainty. 
but for now seems to be free of any major threats to the persistence of the habitat. The two localities in the Sierra Madre de Guerrero, near el Pazclar (Municipality of Leonardo Bravo) and near La Cienega (Municipality of Malinaltepec), are threatened by logging, but it does not appear as widespread as is the case with $T$. papavericola sp. nov. The only known locality of T. tricolor sp. nov. in Oaxaca is threatened by deforestation for small-scale agriculture. We did not see signs of illegal logging or drug cultivation in this area, however in general the habitat in this area is more disturbed than in the vicinity of the type locality.

The Environmental Vulnerability Score (EVS) was developed by Wilson and McCranie (1992) for use with amphibians in Honduras. The EVS system was later applied to the amphibians and reptiles of Mexico by Wilson et al. (2013). It was further modified by Porras et al. (2013) to better apply to animals outside of Honduras. Grünwald et al. (2015) applied the EVS system as modified by Porras et al. (2013) and defined Biogeographical Formations specific to reptiles and amphibians for the country of Mexico. These more-inclusive Biogeographical Formations replaced the "Forest Formations" initially outlined by Wilson and McCranie (1992) in their application to Honduras. Herein we apply the EVS system as outlined by Porras et al. (2013) and Grünwald et al. (2015) to the Tropidodipsas fasciata species group as defined above.

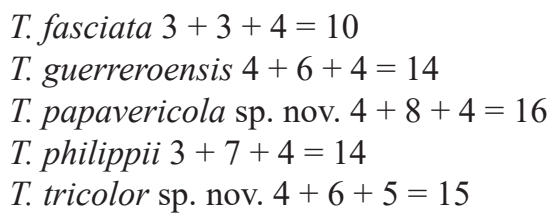

The IUCN categories for assigning conservation status are the most commonly used scheme to assess the degree of extinction risk for taxa at the species level (Porras 2013). The criteria used for this assessment are stipulated in the Guidelines for Using IUCN Red List Categories and Criteria (Version 8.1; August 2010). We evaluate the species of the T. fasciata species group (as defined herein) below:
T. fasciata $=$ Least Concern
T. guerreroensis $=$ Least Concern
T. papavericola $\mathrm{sp}$. nov. $=$ Near Threatened
T. philippii $=$ Least Concern
T. tricolor sp. nov. $=$ Least Concern

Our evaluation of $T$. papavericola sp. nov. as near threatened is based on the limited extent of its known dis- tribution. While known from more localities than just the type locality, all known localities fall within a $90 \mathrm{~km}$ radius of the type locality in the same physiographic province. This fact, coupled with the moderate habitat destruction for small scale agriculture present at all collecting localities, supports our evaluation of this species as "near threatened".

\section{Funding}

Partial funding for the field work was provided by Consejo de Ciencia y Tecnología del Estado de Durango (COCYTED) grant number COCYTED 2018 01: 15088. Further funding for field work was provided by Herp.mx A.C. and Biencom Real Estate. Funding for molecular data generation was provided by the University of South Alabama through startup funds to JLS. IMH was funded by a Summer Undergraduate Research Fellowship from the Office of Undergraduate Research at the University of South Alabama to conduct lab work.

\section{Competing interests}

The authors have declared that no competing interests exist.

\section{Acknowledgements}

First and foremost, we thank our field crew for their courageous enthusiasm to go out in the field in Guerrero, including but not limited to Brandon T. La Forest, André J. Grünwald, Ámbar Lanomy Grünwald, Karen I. Morales-Flores, Janelle Morales-Flores, Carmen Mendoza-Portilla, Nadia Pérez-Rivera, Alejandro Lara, William Mertz and Tziuhtécatl Sánchez Luna. We thank Peter Heimes, Tziuhtécatl Sánchez Luna and Abelino Uriostegui for graciously providing photos of live individuals in the field. Nefti Camacho (LACM), Emily Braker and Christy McCain (UCM), Jeff Weinell and Rafe Brown (KU), David Kizirian (AMNH) and Toby Hibbitts (TCWC) all provided detailed photographs of preserved specimens under their care. We are indebted to María de los Ángeles Palma Irizarry of the Secretaria de Medio Ambiente y Recursos Naturales (SEMARNAT) for providing collecting permits (SGPA/DGVS/002288/18) and to Dr. Juan Miguel Borja-Jiménez for extending his collecting permit to us. We thank Robert Hansen, Arthur Tiutenko, Günter Gollmann and two anonymous reviewers for reviewing our manuscript and providing valuable input.

\section{References}

Alvarez del Toro M, Smith HM (1956) Notulae Herpetologicae Chiapasiae I. Herpetologica 12(1): 3-17.

Arevalo E, Davis SK, Sites Jr JW (1994) Mitochondrial DNA sequence divergence and phylogenetic relationships among eight chromosome races of the Sceloporus grammicus complex (Phrynosomati- dae) in central Mexico. Systematic Biology 43(3): 387-418. https:// doi.org/10.1093/sysbio/43.3.387

Arteaga A, Salazar-Valenzuela D, Mebert K, Peñafiel N, Aguiar G, Sánchez-Nivicela JC, Pyron RA, Colston TJ, Cisneros-Heredia DF, Yánez-Muñoz MH (2018) Systematics of South American snail-eat- 
ing snakes (Serpentes, Dipsadini), with the description of five new species from Ecuador and Peru. ZooKeys 766: 79-147. https://doi. org/10.3897/zookeys.766.24523

Blancas-Hernández JC, Palacios-Aguilar R, Santos-Bibiano R (2019) Tropidodipsas sartorii (Cope, 1863) (Squamata: Dipsadidae): An addition to the snake fauna from Guerrero, Mexico. Herpetozoa 32: 91-93. https://doi.org/10.3897/herpetozoa.32.e35911

Bouckaert R, Vaughan TG, Barido-Sottani J, Duchêne S, Fourment M, Gavryushkina A, Heled J, Jones G, Kühnert D, De Maio N (2019) BEAST 2.5: An advanced software platform for Bayesian evolutionary analysis. PLoS Computational Biology 15(4): e1006650. https:// doi.org/10.1371/journal.pcbi.1006650

Boulenger GA (1894) Catalogue of the snakes in the British Museum (Natural History). Vol. 2. London, British Museum (Natural History), $382 \mathrm{pp}$.

Brown DE, Brennan TC, Unmack PJ (2007)A digitized biotic communities map for plotting and comparing North American plant and animal distributions. Canotia 3(1): 1-12.

Campbell JA (2015) A new species of Rhadinella (Serpentes: Colubridae) from the Pacific versant of Oaxaca, Mexico. Zootaxa 3918(3): 397-405. https://doi.org/10.11646/zootaxa.3918.3.3

Campbell JA, Flores-Villela O (2008) A new long-tailed rattlesnake (Viperidae) from Guerrero, Mexico. Herpetologica 64(2): 246-257. https://doi.org/10.1655/07-054.1

Campbell JA, Smith EN, Hall AS (2018) Caudals and calyces: The curious case of a consumed Chiapan colubroid. Journal of Herpetology 52(4): 458-471. https://doi.org/10.1670/18-042

Campillo G, Dávila-Galavíz LF, Flores-Villela O, Campbell JA (2016) A new species of Rhadinella (Serpentes: Colubridae) from the Sierra Madre del Sur of Guerrero, Mexico. Zootaxa 4103(2): 165-173. https://doi.org/10.11646/zootaxa.4103.2.6

Canseco-Márquez L, Ramírez-González CG, Campbell JA (2018) Taxonomic review of the rare Mexican snake genus Chersodromus (Serpentes: Dipsadidae), with the description of two new species. Zootaxa 4399(2): 151-169. https://doi.org/10.11646/zootaxa.4399.2.1

Davis WB (1953) Notes on the snake Tropidodipsas guerreroensis. Copeia 1953(3): 187-188. https://doi.org/10.2307/1439938

Downs FL (1967) Intrageneric relationships among colubrid snakes of the genus Geophis Wagler. Miscellaneous Publications of the Museum of Zoology, University of Michigan 131: 1-193.

Dugès A (1896) Geophis tecpanecus. Naturaleza Segunda Serie 2: 455-456.

Fernandes R (1995) Phylogeny of the Dipsadine snakes. PhD Thesis, University of Texas at Arlington, Arlington.

Figueroa A, McKelvy AD, Grismer LL, Bell CD, Lailvaux SP (2016) A species-level phylogeny of extant snakes with description of a new colubrid subfamily and genus. PloS One 11: e0161070. https://doi. org/10.1371/journal.pone.0161070

García-Vázquez UO, Pavón-Vázquez CJ, Blancas-Hernández JC, Blancas-Calva E, Centenero-Alcalá E (2018) A new rare species of the Rhadinaea decorata group from the Sierra Madre del Sur of Guerrero, Mexico (Squamata, Colubridae). ZooKeys 780: 137-154. https:// doi.org/10.3897/zookeys.780.25593

Glenn TC, Nilsen RA, Kieran TJ, Sanders JG, Bayona-Vásquez NJ, Finger JW, Pierson TW, Bentley KE, Hoffberg SL, Louha S (2019) Adapterama I: universal stubs and primers for 384 unique dual-indexed or 147,456 combinatorially-indexed Illumina libraries (iTru \& iNext). PeerJ 7: e7755. https://doi.org/10.7717/peerj.7755
Grünwald C, Jones J, Franz-Chávez H, Ahumada-Carrillo I (2015) A new species of Ophryacus (Serpentes: Viperidae: Crotalinae) from eastern Mexico, with comments on the taxonomy of related pitvipers. Mesoamerican Herpetology 2(4): 387-416.

Harvey MB (2008) New and poorly known Dipsas (Serpentes: Colubridae) from northern South America. Herpetologica 64(4): 422-451. https://doi.org/10.1655/07-068R1.1

Harvey MB, Barker DG, Ammerman LK, Chippindale PT (2000) Systematics of pythons of the Morelia amethistina complex (Serpentes: Boidae) with the description of three new species. Herpetological Monographs 14: 139-185. https://doi.org/10.2307/1467047

Harvey MB, Embert D (2008) Review of Bolivian Dipsas (serpentes: colubridae), with comments on other South American species. Herpetological Monographs 22(1): 54-105. https://doi.org/10.1655/07-023.1

Hernández-Jiménez CA, Flores-Villela O, Campbell JA (2019) A new species of patch-nosed snake (Colubridae: Salvadora Baird and Girard, 1853) from Oaxaca, Mexico. Zootaxa 4564(2): 588-600. https://doi.org/10.11646/zootaxa.4564.2.14

Kofron CP (1980) A revision of the Central American slug-eating snakes in the Tropidodipsas complex of the genus Sibon (Serpentes, Colubridae). PhD Thesis, Texas: Texas A\&M University, College Station.

Kofron CP (1982) A review of the Mexican snail-eating snakes, Dipsas brevifacies and Dipsas gaigeae. Journal of Herpetology 16(4): 270-286. https://doi.org/10.2307/1563719

Kofron CP (1985a) Review of the Central American colubrid snakes, Sibon fischeri and S. carri. Copeia 1985: 164-174. https://doi. org/10.2307/1444806

Kofron CP (1985b) Systematics of the Neotropical gastropod-eating snake genera, Tropidodipsas and Sibon. Journal of Herpetology 19(2): 84-92. https://doi.org/10.2307/1564423

Kofron CP (1987) Systematics of Neotropical gastropod-eating snakes: the fasciata group of the genus Sibon. Journal of Herpetology 21(3): 210-225. https://doi.org/10.2307/1564485

Kofron CP (1988) Systematics of Neotropical gastropod-eating snakes: the sartorii group of the genus Sibon. Amphibia-Reptilia 9(2): 145168. https://doi.org/10.1163/156853888X00558

Kofron CP (1990) Systematics of Neotropical gastropod-eating snakes: the dimidiata group of the genus Sibon, with comments on the nebulata group. Amphibia-Reptilia 11(3): 207-223. https://doi. org/10.1163/156853890X00131

Kück P, Longo GC (2014) FASconCAT-G: extensive functions for multiple sequence alignment preparations concerning phylogenetic studies. Frontiers in Zoology 11(1): 1-8. https://doi.org/10.1186/ s12983-014-0081-X

Kumar S, Stecher G, Li M, Knyaz C, Tamura K (2018) MEGA X: molecular evolutionary genetics analysis across computing platforms. Molecular Biology and Evolution 35(6): 1547-1549. https://doi. org/10.1093/molbev/msy096

Lanfear R, Calcott B, Ho SY, Guindon S (2012) PartitionFinder: combined selection of partitioning schemes and substitution models for phylogenetic analyses. Molecular Biology and Evolution 29(6): 1695-1701. https://doi.org/10.1093/molbev/mss020

Lotzkat S, Hertz A, Koehler G (2012) A new species of Sibon (Squamata: Colubroidea: Dipsadidae) from the Cordillera Central of western Panama, with comments on other species of the genus in the area. Zootaxa 3485(1): 26-40. https://doi.org/10.11646/zootaxa.3485.1.2 Mata-Silva V, Johnson JD, Wilson LD, García-Padilla E (2015) The herpetofauna of Oaxaca, Mexico: composition, physiographic 
distribution, and conservation status. Mesoamerican Herpetology 2(1): 6-62.

Mertz WH, Reyes-Velasco J, Grünwald CI (2010) Tropidodipsas fasciata (Banded snail sucker). Herpetological Review 41(4): 520.

Miller MA, Pfeiffer W, Schwartz T (2011) The CIPRES science gateway: a community resource for phylogenetic analyses. In: Proceedings of the 2011 TeraGrid Conference: Extreme Digital Discovery. 1-8 pp. https://doi.org/10.1145/2016741.2016785

Noonan BP, Chippindale PT (2006) Dispersal and vicariance: the complex evolutionary history of boid snakes. Molecular Phylogenetics and Evolution 40(2): 347-358. https://doi.org/10.1016/j. ympev.2006.03.010

Palacios-Aguilar R, Flores-Villela O (2018) An updated checklist of the herpetofauna from Guerrero, Mexico. Zootaxa 4422(1): 1-24. https://doi.org/10.11646/zootaxa.4422.1.1

Palumbi SR (1996) Nucleic acids II: the polymerase chain reaction. Molecular Systematics: 205-247.

Pavón-Vázquez CJ, García-Vázquez UO, Blancas-Hernández JC, Nieto-Montes de Oca A (2011) A new species of the Geophis sieboldi group (Squamata: Colubridae) exhibiting color pattern polymorphism from Guerrero, Mexico. Herpetologica 67(3): 332-343. https://doi.org/10.1655/HERPETOLOGICA-D-11-00003.1

Peters JA (1960) The snakes of the subfamily Dipsadinae. Miscellaneous Publications, Museum of Zoology, University of Michigan 114: 1-224.

Peters WCH (1870) Über neue Amphien (Hemidactylus, Urosaura, Tropdolepisma, Geophis, Uriechis, Scaphiophis, Hoplocephalus, Rana, Entomoglossus, Cystignathus, Hylodes, Arthroleptis, Phyllobates, Cophomantis) des Königlich Zoologisch Museum. Monatsberichte der Königlichen Preussische Akademie des Wissenschaften zu Berlin 1870: 641-652.

Porras LW, Wilson LD, Schuett GW, Reiserer RS (2013) A taxonomic reevaluation and conservation assessment of the common cantil, Agkistrodon bilineatus (Squamata: Viperidae): a race against time. Amphibian and Reptile Conservation 7(1): 48-73.

Pyron RA, Burbrink FT, Colli GR, De Oca ANM, Vitt LJ, Kuczynski CA, Wiens JJ (2011) The phylogeny of advanced snakes (Colubroidea), with discovery of a new subfamily and comparison of support methods for likelihood trees. Molecular Phylogenetics and Evolution 58(2): 329-342. https://doi.org/10.1016/j.ympev.2010.11.006

Rambaut A (2014) FigTree 1.4. 2 software. Institute of Evolutionary Biology, University of Edinburgh.

Rambaut A, Suchard M, Xie D, Drummond A (2015) Tracer v1. 6. 2014.
Rohland N, Reich D (2012) Cost-effective, high-throughput DNA sequencing libraries for multiplexed target capture. Genome Research 22(5): 939-946. https://doi.org/10.1101/gr.128124.111

Ronquist F, Teslenko M, Van Der Mark P, Ayres DL, Darling A, Höhna S, Larget B, Liu L, Suchard MA, Huelsenbeck JP (2012) MrBayes 3.2: efficient Bayesian phylogenetic inference and model choice across a large model space. Systematic Biology 61(3): 539-542. https://doi.org/10.1093/sysbio/sys029

Scott NJ (1967) The colubrid snake, Tropidodipsas annulifera, with reference to the status of Geatractus, Exelencophis, Chersodromus annulatus, and Tropidodipsas malacodryas. Copeia 1967(2): 280-287. https://doi.org/10.2307/1442115

Sheehy CM (2013) Phylogenetic relationships and feeding behavior of Neotropical snail-eating snakes (Dipsadinae, Dipsadini). PhD Thesis, University of Texas at Arlington, Arlington.

Smith HM (1982) The gender of the nominal snake genus Sibon. Bulletin of the Maryland Herpetological Society 18(4): 192-193.

Smith HM, Lemos-Espinal JA, Hartman D, Chiszar D (2005) A new species of Tropidodipsas (Serpentes: Colubridae) from Sonora, Mexico. Bulletin of the Maryland Herpetological Society 41(1): 39-41.

Taylor EH (1939) Some Mexican Serpents. 26(14): 445-487.

Townsend TM, Alegre RE, Kelley ST, Wiens JJ, Reeder TW (2008) Rapid development of multiple nuclear loci for phylogenetic analysis using genomic resources: an example from squamate reptiles. Molecular Phylogenetics and Evolution 47: 129-142. https://doi. org/10.1016/j.ympev.2008.01.008

Uetz P (2021) Dipsadinae. https://reptile-database.reptarium.cz/search?search=Dipsadinae\&submit=Search [accessed May 3rd, 2021]

Wallach V (1995) Revalidation of the genus Tropidodipsas Günther, with notes on the Dipsadini and Nothopsini (Serpentes: Colubridae). Journal of Herpetology 29(3): 476-481. https://doi. org/10.2307/1565006

Wilson LD, Mata-Silva V, Johnson JD (2013) A conservation reassessment of the reptiles of Mexico based on the EVS measure. Amphibian \& Reptile Conservation 7(1): 1-47.

Wilson LD, McCranie JR (1992) Status of amphibian populations in Honduras. Unpublished Report to the Task Force on Declining Amphibian Population, 15 August 1992, 14 pp.

Zheng Y, Wiens JJ (2016) Combining phylogenomic and supermatrix approaches, and a time-calibrated phylogeny for squamate reptiles (lizards and snakes) based on 52 genes and 4162 species. Molecular Phylogenetics and Evolution 94(Part B): 537-547. https://doi. org/10.1016/j.ympev.2015.10.009

io de Tecomán, 494 m a.s.1., JAC 28587 • Guerrero: $10.8 \mathrm{~km} \mathrm{~N}$ of Hwy. 200 on Hwy. 134, Municipio de Jose Azueta, $130 \mathrm{~m}$ a.s.1., JRV 0030.

Dipsas brevifacies. - Mexico: Yucatan $36.4 \mathrm{~km} \mathrm{~S} \mathrm{of}$ Valladolid on Hwy. 295, Municipio de Tixcacalcupul, 25 m a.s.1., INIRENA 2791, CIG $1841 \cdot 1.4 \mathrm{~km}$ $\mathrm{E}$ of fair complex on Calle 253, Merida, Municipio de Merida, $11 \mathrm{~m}$ a.s.l., INIRENA 2792, CIG 1844.

Dipsas gaigeae.- Mexico: Colima $\cdot 3.0 \mathrm{~km} \mathrm{~N}$ of Ixtlahuacán Rd. on Hwy. 54 frontage road, Municipio de Tecomán, $322 \mathrm{~m}$ a.s.1., JAC $28327 \bullet 6.4 \mathrm{~km} \mathrm{~N}$ of Ixtlahuacán Rd. on Hwy. 54 frontage road, Municip-
Geophis annuliferus comb. nov.-Mexico: Colima $・$ El Mixcuate, on Colima-Minatitlán Road, Municipio de Villa de Álvarez, 569 m a.s.l., JAC 30142 • Guerrero: $24.1 \mathrm{~km} \mathrm{NE}$ of Hwy. 200 on Hwy. 134, Municipio de José Azueta, $330 \mathrm{~m}$ a.s.l. JAC 27792.

Geophis bicolor.- Mexico: Colima $10 \mathrm{~km}$ (airline) NNW of Quesería, Municipio de Cuauhtémoc, 2128 m a.s.1., INIRENA 2795-97, CIG 1786-88• Jalisco: 
$3 \mathrm{~km}$ (airline) NNW of Cumbre de Guadalupe, $\mathrm{Mu}$ nicipio de Talpa de Allende, $2095 \mathrm{~m}$ a.s.1., INIRENA 2793-94, CIG 1576-77 • 9.2 km SW of Tapalpa on road to San Gabriel, Municipio de Tapalpa, $2012 \mathrm{~m}$ a.s.1., INIRENA 2808, CIG $1850 \bullet$ Plan de Cervantes, on Valle de Juárez - Santa María del Oro Rd., Municipio de Quitupan, $2291 \mathrm{~m}$ a.s.1. INIRENA 2809, CIG 1851 Michoacán: $3.2 \mathrm{~km} \mathrm{NW}$ of Apo, Municipio de Tancítaro, $2010 \mathrm{~m}$ a.s.1., JAC 24684.

Geophis nigrocinctus.-Mexico: Jalisco • Cerro Tetilla, $20.1 \mathrm{~km}$ (airline) W of Talpa de Allende, Municipio de Talpa de Allende, 2466 m a.s.l., JAC 30704 • Michoacán: Between Paso Malo and Rancho Las Torrecillas, on Coalcomán-Dos Aguas Rd., Municipio de Coalcomán de Vázquez-Pallares, 2115 m a.s.1., CIG 0568.

Geophis omiltemanus.- Mexico: Guerrero • Omiltemi, Municipio de Chilpancingo de los Bravo, $2115 \mathrm{~m}$ a.s.1., ENS 11496.

Geophis sanniolus comb. nov.- Mexico: Yucatan • $2.2 \mathrm{~km}$ E of Homún on road to Huhi, Municipio de Homún, 16 m a.s.l., INIRENA 2790, CIG 1842• 12.7 $\mathrm{km} \mathrm{S}$ of Hwy. 180 on road to Tahdzibichén, Municipio de Yaxcabá, $30 \mathrm{~m}$ a.s.1., JAC $24409 \cdot 2.8 \mathrm{~km} \mathrm{~S}$ of Tixcacalcupul on Hwy. 295, Municipio de Tixcacalcupul, 26 m a.s.1., INIRENA 2789, CIG 1839.

Geophis sartorii comb. nov.-Mexico: San Luis Potosí • $1.1 \mathrm{~km} \mathrm{SW}$ of Huichihuayan, on road to El Nacimiento, Municipio de Huehuetlán, $90 \mathrm{~m}$ a.s.l., INIRENA 2784, CIG 1758 • $2.0 \mathrm{~km}$ NE of Xilitla on Hwy. 120, Municipio de Xilitla, $552 \mathrm{~m}$ a.s.1., INIRENA 2785, CIG $1759 \cdot 2.2 \mathrm{~km}$ NE of Xilitla on road to El Túnel, Municipio de Xilitla, $679 \mathrm{~m}$ a.s.l., INIRENA 2783, CIG 1518 - Yucatan: $6.7 \mathrm{~km} \mathrm{~S}$ of Tixcacalcupul on Hwy. 295, Municipio de Tixcacalcupul, 26 m a.s.1., INIRENA 2786, CIG 1840 • Unknown: JAC 30401.

Geophis tarascae.- Mexico: Colima $-7 \mathrm{~km}$ (airline) NNW of Montitlán, Municipio de Cuahutémoc, 1846 m a.s.1., INIRENA 2807, CIG 1631 • Jalisco: 1.9 km S of El Montoso, Municipio de Quitupan, $1969 \mathrm{~m}$ a.s.1., INIRENA 2806, CIG 1372 • Michoacán: 2.5 $\mathrm{km} \mathrm{S}$ of southern edge of Uruapan, on Hwy. 37 libre toward Lombardia, Municipio de Uruapan, 1563 m a.s.1., JAC 24692.

Sibon nebulatus.- Mexico: Chiapas - $0.8 \mathrm{~km} \mathrm{SW}$ of Ejido Morelos, Municipio de Huixtla, 1185 m a.s.l. INIRENA 2788, CIG 0788 - Colima: Road from Comala to Minatitlán, 739 m a.s.l., JAC 30102 • Hwy. 54 frontage road, near La Salada, 301 m a.s.l., JAC 30124 - Michoacán: $9.4 \mathrm{~km}$ NNW of Caleta de Campos, Municipio de Aquila, 15 m a.s.1., INIRENA 2787, CIG 1481.

Tropidodipsas fasciata.- Mexico: Chiapas • $13.5 \mathrm{~km}$ (airline) NW of Rizo de Oro, Municipio de Cintalapa, elev. unknown, JAC 22920 - Oaxaca: $33.6 \mathrm{~km}$ SSE Matias Romero, Municipio de Asunción Ixaltepec, LACM $103765 \cdot 17.3 \mathrm{~km} \mathrm{~W}$ of Zanatepec, Municipio de Santiago Niltepec, 56 m a.s.l., LACM
$38212 \cdot 3.2 \mathrm{~km} \mathrm{~N}$ of Tehuantepec, Municipio de Santo Domingo Tehuantepec, $32 \mathrm{~m}$ a.s.l., LACM 114067 - $60.8 \mathrm{~km}$ WNW of Tehuantepec on Hwy. 190, Municipio de Magdalena Tequisistlán, LACM 74042 • $51.2 \mathrm{~km} \mathrm{NW}$ of Magdalena Tequisistlán turnoff on Hwy. 190 to Oaxaca, Municipio de Nejapa de Madero, LACM $38211 \cdot 2.9 \mathrm{~km} \mathrm{~W}$ of Hwy. 195 on road to Almoloyas, Municipio de El Barrio de la Soledad, $270 \mathrm{~m}$ a.s.1., JAC 30740.

Tropidodipsas sp. cf. fasciata - Mexico: Tamaulipas • Gómez-Farías Rd., at the Ojo de Agua turnoff, Municipio de Gómez Farías, 243 m a.s.l., CIG 0819 • Yucatan: $15.4 \mathrm{~km}$ NW of Hunucmá on road to Sisal, Municipio de Hunucmá, 5 m a.s.l., INIRENA 2780, CIG 1843.

Tropidodipsas fischeri.- Mexico: Chiapas • Selva Negra, Municipio de Rayón, 1895 m a.s.1., CHFCB-0352 - Chichihuites, Municipio de Unión Juárez, 2090 m a.s.1., CHFCB-0332, 0335.

Tropidodipsas guerreroensis.- Mexico: Guerrero: Acahuizotla, $853 \mathrm{~m}$ a.s.1., KU 61242, TCWC 7477-80 • $1.6 \mathrm{~km}$ W Acahuizotla, $853 \mathrm{~m}$ a.s.1., TCWC 7481-82 - $2.8 \mathrm{~km}$ SW of Rincón de la Parotas, on Atoyac de Álvarez to Puerto del Gallo Rd., Municipio de Atoyac de Álvarez, 273 m a.s.l., INIRENA 2781, CIG 1857 • Oaxaca: $12 \mathrm{~km} \mathrm{~S}$ of Candelaria Loxicha on Hwy. 175, Municipio de Candelaria Loxicha, $291 \mathrm{~m}$ a.s.l., JAC 24267 - 1.6 km SE of Cacahuatepec, Municipio de San Juan Cacahuatepec, 360 m a.s.1., UIMNH 52958.

Tropidodipsas papavericola sp. nov.- Mexico: Guerrero $12.5 \mathrm{~km} \mathrm{~S}$ of Puerto del Gallo on road from Nuevo Dehli to Puerto del Gallo, Municipio de Atoyac de Álvarez, 1914 m a.s.1., INIRENA 2801, CIG 1495 • $18.1 \mathrm{~km} \mathrm{~S}$ of Puerto del Gallo on road from Nuevo Dehli to Puerto del Gallo, Municipio de Atoyac de Álvarez, 1654 m a.s.l., INIRENA 2802, CIG 1496 - $5 \mathrm{~km} \mathrm{~S}$ of La Laguna, on road from San Luis La Loma to Bajitos de la Laguna, Municipio de Técpan de Galeana, 1686 m a.s.l., INIRENA 2803 CIG 1502 - Bajitos de la Laguna, Municipio de Técpan de Galeana, INIRENA 2804, CIG 1632 • Jaguar Research Facility, Municipio de Técpan de Galeana, INIRENA 2805 , CIG $1457 \cdot 4.2 \mathrm{~km} \mathrm{~S}$ of La Laguna, on San Luis San Pedro - La Laguna Rd., Municipio de Técpan de Galeana, 1620 m a.s.1., INIRENA 2810, JRV 0362.

Tropidodipsas philippii.-Mexico: Colima $-2 \mathrm{~km}$ E of Hwy. 54 frontage road on road to Ixtlahuacán, Municipio de Ixtlahuacán, $346 \mathrm{~m}$ a.s.1., INIRENA 2782, CIG 1503 - San Gabriel, Municipio de Ixtlahuacán, $490 \mathrm{~m}$ a.s.l., CIG $0902 \cdot 2 \mathrm{~km} \mathrm{~S}$ of Minatitlán, on Hwy. 98, Municipio de Minatitlán, 712 m a.s.1., JAC 28262 • 16-24 km SW Colima, LACM 59146 • Jalisco: $8.6 \mathrm{~km} \mathrm{~N}$ of El Tuito on Hwy. 200, Municipio de Cabo Corrientes, 702 m a.s.1., ENS 11639 - Nayarit: Las Mesas, Municipio de Tepic, $338 \mathrm{~m}$ a.s.1., JAC 24811 • Michoacán: $2.4 \mathrm{~km} \mathrm{~N}$ of Hwy. 200 on road to Ostula, Municipio de Aquila, $138 \mathrm{~m}$ a.s.1., JAC 27923 - Sinaloa: $10.1 \mathrm{~km} \mathrm{NE}$ of Concordia turnoff on Hwy. 40-D cuota, on road to Durango, 
Municipio de Concordía, 287 m a.s.1., JAC 30601 • $85.3 \mathrm{~km} \mathrm{~N}$ of Mazatlán, LACM $7118 \cdot 57.9 \mathrm{~km} \mathrm{~N}$ of Mazatlan, KU 73640; 50.9 km N Mazatlan, LACM 7119 • between Escuinapa and Palmilla, LACM 7117 - Teacapan, LACM 7116.

Tropidodipsas sp. cf. philippii.— Mexico: Oaxaca • 5.1 $\mathrm{km} \mathrm{S}$ of Jalatengo, Municipio de Candelaria Loxicha, 1390 m a.s.1., KU 137655 • Santa Rosa, Distrito Lachao, Municipio de San Juan Lachao, UCM 49372

- $27.4 \mathrm{~km} \mathrm{~S}$ of Juchatengo, Municipio de San Juan Lachao, 1829 m a.s.1., LACM 104321.

Tropidodipsas tricolor sp. nov. - Mexico: Guerrero • $1.5 \mathrm{~km}$ east of Río Verde, Municipio de Atoyac de Álvarez, $971 \mathrm{~m}$ a.s.1., INIRENA 2800, CIG 1837 • $4.5 \mathrm{~km} \mathrm{NW}$ of Mixtecapa, on road to Malinaltepec, Municipio de Malinaltepec, $1815 \mathrm{~m}$ a.s.1., INIRENA 2798, CIG 1863 - Oaxaca: $26 \mathrm{~km}$ N of Putla Villa de Guerrero, on Putla Villa de Guerrero - Oaxaca Hwy., Municipio of Putla de Guerrero, 1785 m a.s.l., INIRENA 2799, CIG 1596.

\section{Supplementary material 1}

\section{Table S1}

Authors: Christoph I. Grünwald, Sarahi Toribio-Jiménez, Sarahi Toribio-Jiménez, Héctor Franz-Chávez, Miguel A. Peñaloza-Montaño, Eduardo Y. Barrera-Nava, Jason M. Jones, Christopher M. Rodriguez, India M. Hughes, Jason L. Strickland, Jacobo Reyes-Velasco

Data type: species data

Explanation note: Morphological differences between the new species of Tropidodipsas and other snail-suckers from Mexico.

Copyright notice: This dataset is made available under the Open Database License (http://opendatacommons.org/licenses/ odbl/1.0/). The Open Database License (ODbL) is a license agreement intended to allow users to freely share, modify, and use this Dataset while maintaining this same freedom for others, provided that the original source and author(s) are credited.

Link: https://doi.org/10.3897/herpetozoa.34.e69176.supp11 